Motu Working Paper 21-13

\title{
Future Options for Industrial Free Allocation in the NZ ETS
}

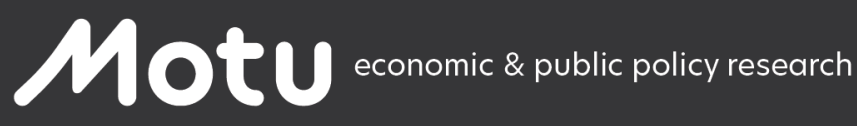

Benjamin Rontard and Catherine Leining

September 2021 


\section{Document information}

\section{Author contact details}

Benjamin Rontard

Autonomous University of San Luis Potosí

brontard@gmail.com

Catherine Leining

Motu Economic and Public Policy Research

catherine.leining@motu.org.nz

\section{Acknowledgements}

This work was conducted under Motu's programme Shaping New Zealand's Low-Emission Future with funding support from the Aotearoa Foundation. The ideas in this document were developed through, informed by, and inspired by discussions among ETS Dialogue participants, which were undertaken in their personal capacity. We are grateful for review comments provided by William Acworth, Ted Jamieson, Christopher Kardish, and Suzi Kerr.

\section{Disclaimer}

The inclusion of the ideas in this document does not imply any recommendation, consensus, or endorsement by ETS Dialogue participants or presenters, their affiliated organisations, or the programme funder. All opinions, errors, and omissions are the authors' own.

\section{Motu Economic and Public Policy Research}

PO Box 24390

Wellington

www.motu.org.nz

New Zealand

(C) 2021 Motu Economic and Public Policy Research Trust and the authors. Short extracts, not exceeding two paragraphs, may be quoted provided clear attribution is given. Motu Working Papers are research materials circulated by their authors for purposes of information and discussion. They have not necessarily undergone formal peer review or editorial treatment. ISSN 1176-2667 (Print), ISSN 1177-9047 (Online). 


\section{Abstract}

The provision of industrial free allocation can be one of the most technically challenging and politically fraught elements of designing an emissions trading system (ETS). In the New Zealand Emissions Trading Scheme (NZ ETS), the primary rationales for industrial free allocation have been to mitigate the risk of emissions leakage to other jurisdictions and avoid economic regrets from losing domestic production that would be viable if other jurisdictions adopted more ambitious climate change policies. Over 2010-2020, emissions-intensive and trade-exposed (EITE) industrial producers received free allocation on an output basis at two levels of assistance (90 per cent and 60 per cent) without an absolute limit. In 2020, major reform legislation introduced default phase-out pathways over 2021-2050 for industrial free allocation, with the potential for future activity-specific adjustment. The government has signalled it will consider broader changes post-2021 to avoid overallocation while still mitigating the risk of emissions leakage overseas. To help inform future policy making on these issues, this paper examines conceptual design issues for free allocation in an ETS, describes the regime for industrial free allocation in the NZ ETS, and provides comparative analysis with three other systems. It then identifies a range of options for further reform: changing the eligibility criteria, changing the calculation methodology, substituting alternative measures, or accepting and managing emissions leakage. Further research will be needed to evaluate the merits of these options. More fundamentally, the government should consider whether the public and private benefits of maintaining and improving industrial free allocation are worth the cost and complexity in the evolving international and domestic contexts. Ultimately, any future provision of industrial free allocation should be used to assist - and not block - the transition to an economy that rewards low-emission innovation.

\section{JEL codes}

Q54, Q58

\section{Keywords}

Emissions trading, free allocation, industry, climate change mitigation, New Zealand

\section{Summary haiku}

Free allocation

shelters firms from carbon costs

but not forever 


\section{Table of contents}

1 Introduction $\quad 1$

2 Conceptual design issues for free allocation $\quad 1$

2.1 How emissions trading works $\quad 1$

2.2 What is free allocation? 2

$\begin{array}{lll}2.3 & \text { Rationales for free allocation } & 2\end{array}$

2.4 A deeper look at carbon leakage $\quad 4$

$\begin{array}{lll}2.5 & \text { Methodologies for free allocation } & 6\end{array}$

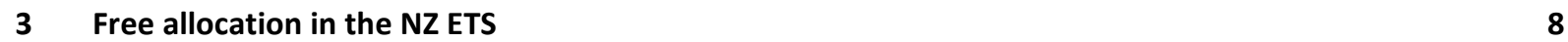

$\begin{array}{llr}3.1 & \text { Policy history of free allocation } & 8\end{array}$

$\begin{array}{ll}3.2 & \text { Current policy framework for industrial free allocation } \\ \end{array}$

$\begin{array}{lll}3.3 & \text { Profile of industrial free allocation through } 2020 & 13\end{array}$

$\begin{array}{lll}3.4 & \text { Outlook for industrial free allocation post-2021 } & 18\end{array}$

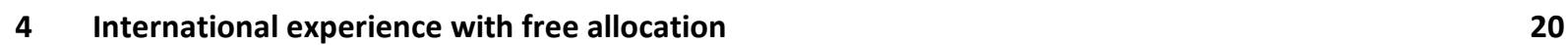

$\begin{array}{lll}4.1 & \text { European Union Emissions Trading System (EU ETS) } & 20\end{array}$

$\begin{array}{llr}4.2 & \text { California Cap-and-Trade Program } & 24\end{array}$

$\begin{array}{lll}4.3 & \text { Australian Carbon Pricing Mechanism (CPM) } & 27\end{array}$

$5 \quad$ Options for improving industrial free allocation in the NZ ETS post-2021 30

$\begin{array}{lll}5.1 & \text { Eligibility to receive free allocation } & 31\end{array}$

$\begin{array}{lll}5.2 & \text { Methodology for calculating industrial free allocation } & 36\end{array}$

$\begin{array}{lll}5.3 & \text { Alternatives to industrial free allocation } & 43\end{array}$

$\begin{array}{lll}5.4 & \text { Accepting and managing emissions leakage } & 46\end{array}$

$\begin{array}{lll}5.5 & \text { Summary of future options for industrial free allocation } & 46\end{array}$

$6 \quad$ Cross-cutting considerations $\quad 53$

$\begin{array}{llr}6.1 & \text { Considering sectoral equity } & 53\end{array}$

6.2 Maintaining predictability of unit supply for efficient price setting 53

$\begin{array}{lll}6.3 & \text { Enabling policy stability } & 54\end{array}$

7 Conclusion $r$

$\begin{array}{lr}\text { References } & 57\end{array}$ 


\section{Figures and tables}

Figure 1: Trends in industrial free allocation in the NZ ETS: 2010 to 2018

Figure 2: Estimated market value of industrial free allocation in the NZ ETS: 2010 to 2018

Figure 3: Percentage of NZUs freely allocated by activity (2018)

Figure 4: Impacts of carbon prices on firm profits, current ETS scope

Table 1: Eligible activities for free allocation in the NZ ETS

Table 2: Assistance factor (AF) for non-EITE industrial sectors

Table 3: Linear reduction factor (LRF) and cross-sectoral correction factor (CSCF) for Phase III of the EU ETS

Table 4: Cap adjustment factor between 2013 and 2020 in the California Cap-and-Trade Program

Table 5: Carbon leakage risk categories from the California Air Resources Board 





\section{Introduction}

Emissions trading systems (ETSs) are an effective mechanism to assist jurisdictions to reduce their greenhouse gas (GHG) emissions and combat climate change. As of 2020, 21 systems were in place worldwide, covering 27 jurisdictions and 9 per cent of global emissions. An additional 24 jurisdictions are developing or considering an ETS (International Carbon Action Partnership 2020). These systems all differ in their level of emission reduction and price ambition, the sectors and gases they cover, the activities that are covered within each sector, how emission units are allocated, and how they link with other sources of emission units.

Reflecting its national context, the New Zealand Emissions Trading Scheme (NZ ETS) was launched in 2008 with a number of innovative design features that differ markedly from many other ETSs under operation or consideration. Having evolved for over a decade under the global carbon market framework and domestic mitigation objectives established pursuant to the 1997 Kyoto Protocol, the NZ ETS now requires reforms to operate in the new context created by the 2015 Paris Agreement.

This paper is part of a series of Motu papers on the history, evaluation, and outlook for the NZ ETS. The focus of this paper is on the use of industrial free allocation. First, the paper examines conceptual design issues for free allocation in an ETS. It then describes the policy settings for free allocation in the NZ ETS and provides comparative analysis with other systems (the European Union Emissions Trading System [EU ETS], California Cap-and-Trade Program [CA CAT], and Australian Carbon Pricing Mechanism [CPM]). The paper concludes by examining options for changing industrial free allocation in the NZ ETS post-2021 and associated research and policy needs. ${ }^{1}$

\section{Conceptual design issues for free allocation}

\subsection{How emissions trading works}

GHG emissions impose a cost on the economy that is not accounted for in standard market transactions. As a result, producers and consumers receive the economic benefits of emitting activities while the environmental costs are distributed globally and over time. Similarly, those who take action to reduce emissions face the costs but do not receive the benefits, which are

\footnotetext{
${ }^{1}$ We note that in July 2021, the New Zealand Government initiated consultation on reforming industrial free allocation in the NZ ETS (Ministry for the Environment 2021b). This paper was prepared prior to the release of the Government's consultation document and does not address its content.
} 
distributed globally and over time. A well-designed ETS should integrate a price on emissions into market transactions, creating incentives for producers and consumers to choose loweremission alternatives and enabling innovators to compete. Under conventional ETS design, the government imposes a limit (cap) on the total emissions in covered sectors of the economy and issues tradable emission units equal to the level of the cap. Each unit corresponds to one tonne of emissions, and regulated participants must surrender emission units to cover the emissions for which they are liable. The establishment of a trading market and a fixed number of units generates a unit price. Constraining unit supply relative to demand raises emission prices and incentivises behaviour change (Partnership for Market Readiness and International Carbon Action Partnership 2016; Leining et al. 2019).

\subsection{What is free allocation?}

"Allocation" refers to the process by which the government issues emissions units into the market for an ETS. Allocation generally occurs through three mechanisms: selling units at auction, distributing units to market participants for free, or awarding units for eligible removal activities within the ETS. Some systems also accept units from external offsetting (typically project-based) mechanisms. The market sets emission prices based on the balance between total unit supply and demand; this is not affected by how units are distributed into the market. However, the method of allocation affects how the costs of compliance with ETS obligations are distributed across the market and can influence participants' level of exposure to emissions pricing and their relative incentive to change behaviour. Free allocation also has fiscal implications for the government, which forgoes the auction revenue that would otherwise be received.

In most ETSs, the regulator sells a portion of units through auctions and distributes the other portion through free allocation. Among the 21 ETSs in force in 2020, four used free allocation only, one used auctioning only, and 16 applied (or enabled) both options (International Carbon Action Partnership 2020; Li and Binliang 2020). Some ETSs started with 100 per cent free allocation and have introduced auctioning over time (Narassimhan et al. 2018).

\subsection{Rationales for free allocation}

For firms producing emissions-intensive outputs, emissions pricing causes a direct increase in production costs that can affect asset values, profitability, market share, and workers, with flowon effects for the local and national economy (Partnership for Market Readiness and International Carbon Action Partnership 2016). Firms vary in their ability to pass on emission 
costs to their customers or otherwise adapt to rising emission costs through efficiency improvements and innovation. While adjusting to such changes may be a constructive and necessary part of the low-emission transition, the means and pace of adjustment can impact on outcomes for the environment as well as the wellbeing of firm owners and investors, workers and communities. Free allocation is one tool for managing the pace and cost of adjustment for producers impacted by emissions pricing. Given the value of units in the trading market, providing free allocation is analogous to handing cash to participants in the form of a lump sum or output subsidy.

How free allocation should be designed and where it should be targeted depend on the core rationale(s) for providing free allocation, such as:

1. Preventing carbon leakage to other jurisdictions

2. Protecting economic competitiveness

3. Reducing stranded assets

4. Enabling a smooth low-emission transition for businesses and communities.

Additional policy considerations when designing free allocation include managing the fiscal implications of freely allocating versus auctioning units, preserving incentives for producers and consumers to reduce emissions in line with targets, appropriately recognising early action to reduce emissions, and deciding who receives free allocation and on what basis (Partnership for Market Readiness and International Carbon Action Partnership 2016; Secretaria de Medio Ambiente y Recursos Naturales and Deutsche Gesellschaft für Internationale Zusammenarbeit 2018).

The issue of preserving incentives for mitigation is particularly important. Producers with unit obligations who receive free allocation still have an incentive to reduce emissions because they face an opportunity cost from using the units for compliance rather than reducing their emissions and selling the surplus units in the market. Whether producers bear a direct cost or opportunity cost from surrendering units to meet an ETS obligation, they have an incentive to reduce that cost where possible, improving their competitiveness, and pass that cost to their customers where possible, incentivising demand-side emission reductions. Producers without unit obligations who receive free allocation as a form of compensation still have an incentive to reduce their consumption of emissions-intensive goods and services that carry an embodied emissions price.

The methods for distributing free allocation - discussed later in this paper - can affect both the average and marginal costs imposed on producers by an ETS, with flow-on effects for 
decisions on output and investment. Importantly, while free allocation does not eliminate incentives for producers to reduce emissions in relation to a particular product or service (for example, by increasing production efficiency), it can distort incentives to substitute toward alternative low-emission products and services that face the full price of emissions (Acworth et al. 2020).

The outcomes sought by providing free allocation can also be achieved in other ways, such as government decisions on the ambition of ETS unit supply and price management settings, the strategic application of ETS auction revenue, border carbon adjustments (BCAs) and consumption charges, and complementary economic, labour, and social policies that support firms, workers, and communities.

\subsection{A deeper look at carbon leakage}

Issues that relate to protecting competitiveness, reducing stranded assets and enabling a smooth transition could arise with any form of environmental, economic, or social regulation affecting New Zealand producers (for example, addressing worker health and safety, child labour, toxic discharges to the environment, consumer protection, etc.). In contrast, the issue of carbon leakage is a consideration unique to climate change mitigation policy and a key focus of this paper.

One group of stakeholders potentially subject to disproportionate impacts from emissions pricing consists of emissions-intensive producers exposed to import or export trade competition from jurisdictions with weaker emissions pricing, higher levels of free allocation, or less stringent regulation of emissions. Such trade-exposed producers may either hold direct surrender obligations in an ETS or be impacted by the emission price passed through the supply chain. Whereas other types of producers have the option to pass on the cost of emissions to their customers, emissions-intensive and trade-exposed (EITE) producers may not be able to do so and continue to remain competitive. If they cannot transition to less emissions-intensive production or absorb the rising cost of emissions (for example, through a fall in associated asset prices such as the value of land), they may be forced to reduce or cease production or not expand as they would have otherwise. This can displace production to other jurisdictions with weaker mitigation regimes, causing local economic and employment effects, as well as shifting emissions to other jurisdictions. This outcome is referred to as "carbon leakage".

An important distinction should be made between the risk of carbon leakage and the risk of profit losses from emissions pricing. EITE producers whose major assets are immobile (both geographically and across sectors) might not have carbon leakage risk but can face large losses in 
profitability. In New Zealand's context, this consideration is particularly relevant to land-based production. For example, in the case where domestic dairy production is significantly more profitable than alternative land uses, its profitability will need to fall considerably before domestic dairy production is displaced offshore due to land-use change as a result of emissions pricing.

Multiple factors determine whether displacing production between jurisdictions results in carbon leakage. One is the relative emissions intensity of producing the commodity in question in the two jurisdictions. Another is whether the jurisdictions have binding absolute emission reduction targets with which they intend to comply. For example, if cement production and emissions shift from New Zealand to a jurisdiction with weaker emissions pricing or regulation for cement, but that jurisdiction has an economy-wide target that compels it compensate with emission reductions elsewhere in the economy, then global emissions may not increase due to production leakage.

The boundaries for assessing carbon leakage impacts can extend beyond the product itself. It is important to consider the full life cycle of emissions of production processes as well as their interdependence on other emissions sources. This includes the embodied emissions in either building new or decommissioning old plant and infrastructure as production shifts between jurisdictions. Carbon leakage can result from increased international transportation required to meet domestic demand for products that are no longer produced locally (an issue for an isolated country like New Zealand). Reduced fossil fuel demand in jurisdictions with more stringent targets can lower global fossil fuel prices and lead to higher consumption of fossil fuels elsewhere (Acworth et al. 2020).

There can also be broader environmental and social impacts from production leakage both positive and negative. Industrial production can impact on ecosystem services (for example, soil and water quality, landscape, and biodiversity). Relocating industrial production can accelerate environmental restoration in one jurisdiction and its degradation in another. Economic losses in one jurisdiction can support economic development in another.

Given the number of factors that contribute to production decisions, it is challenging empirically to assess potential and actual carbon leakage. In ex ante studies, carbon leakage has been estimated with general equilibrium or partial equilibrium modelling approaches. To date, several ex ante studies have focused on the EU ETS and shown potential risk for carbon leakage (Partnership for Market Readiness 2015; Acworth et al. 2020). In the case of California's system, Fowlie et al. (2016) estimated the impact of emissions pricing on carbon leakage by modelling the responsiveness of trade flow to energy price from empirical data. The results show potential 
leakage risk, mostly for industries classified under high leakage risk in the CA CAT. Empirical ex post studies on the topic have mostly focused on the EU ETS and concluded that there is no evidence to date of significant carbon leakage (Partnership for Market Readiness 2015). However, the empirical data used covered the early years of the EU ETS, when free allocation was at 100 per cent for entities. Recent studies in China show the absence of evidence of carbon leakage risk from pilot systems; however, these have typically used extensive free allocation (Fan et al. 2019). International literature reviews of ex post analysis to date suggest that existing emissions pricing models have reduced the level of emissions without impacting the economic performance of business (Ministry for the Environment 2018; High-Level Commission on Carbon Pricing and Competitiveness 2019; Acworth et al. 2020; Verde et al. 2020). Given data limitations as well as the relatively low levels of emissions prices and short operational periods for ETSs to date, these conclusions may not be definitive - or indicative of a future with higher emissions prices and lower levels of free allocation (Acworth et al. 2020).

Another interesting consideration is the potential for investment leakage as a result of emissions pricing (Verde et al. 2020). In one example, Koch and Basse Mama (2019) estimated the impact of the EU ETS on foreign direct investment by German multinational firms directed to non-EU ETS countries between 2005 and 2013. The study indicated that emissions pricing had not caused a significant impact among the total sample. In the case of less capital-intensive industries, they found evidence that emissions pricing had impacted foreign direct investment. But these firms neither operate in the energy-intensive sectors targeted by the EU ETS, nor are they emissions intensive. It is important to note while the future pace of mitigation can be expected to vary across countries, the opportunities to shift investment to countries without meaningful climate change mitigation regimes are likely to fall with implementation of the Paris Agreement and growing international pressure for firms and investors to disclose climate-related risks.

\subsection{Methodologies for free allocation}

Free allocation typically involves a choice among three different methodologies: grandparenting, an output-based approach with infrequent updating, and an output-based approach with frequent updating. Under grandparenting, the regulator distributes units to eligible entities based on historical emissions (generally a percentage of the average absolute emissions over a specified period) and the outcome is generally fixed. Output-based approaches use benchmarks for the emissions intensity of the outputs produced by the firms. Benchmarks are typically derived from recent historical performance or sectoral best practice and can either reflect those 
levels or target improvement beyond those levels. Units are allocated according to benchmarked emissions intensity and the level of output. In the case of infrequent updating, the regulator allocates units based on a fixed level of output in a prior year or average over a prior period. In the case of frequent updating, the allocation is based on the actual level of output in the current year. Typically under an updating model, the firms receive a provisional allocation according to the level of output in the previous year, and this is adjusted as needed when actual annual output has been reported.

Some key points of comparison between grandparenting and output-based free allocation are: ${ }^{2}$

- Under grandparenting, producers receive a fixed amount of free allocation and face a full emission price on marginal increases in production. Under output-based approaches, the amount of free allocation increases as output increases and producers face a fraction of the emissions price at the margin. While the emissions liability incentivises emission intensity improvements, output-based approaches with frequent updating operate like an output subsidy and do not incentivise reductions in production or product substitution. If growing production demand outpaces improvements in emissions intensity, absolute emissions will continue to rise.

- Under suitable conditions, output-based approaches can help prevent carbon leakage whereas grandparenting is less effective or may even incentivise carbon leakage for production beyond grandparented levels. ${ }^{3}$ The fact that output-based approaches can also protect trade competitiveness complicates the political dynamics of reducing free allocation as carbon leakage risks decline.

- Grandparenting can offer relatively greater predictability about the volume of free allocation than output-based approaches. This can be a useful feature for target management in jurisdictions with significant proportions of free allocation in their ETS. Under output-based approaches with frequent updating, the volume of free allocation fluctuates with actual production. To support targets, some systems (for example, in the

\footnotetext{
${ }^{2}$ For further discussion, see Partnership for Market Readiness and International Carbon Action Partnership (2016) and Secretaria de Medio Ambiente y Recursos Naturales and Deutsche Gesellschaft für Internationale Zusammenarbeit (2018). ${ }^{3}$ With grandparenting, there may be an incentive for a firm to reduce output in the ETS jurisdiction to just above the level that would trigger any closure rule or limit that the ETS imposes, in order to retain the asset of free allocation, and shift incremental production elsewhere. Acworth et al. (2020) explain that a range of factors can determine whether outputbased free allocation is effective at preventing carbon leakage by narrowing the emissions cost gap between production in different jurisdictions. As discussed later in the paper, these include the relative emissions prices, emissions intensities, levels of free allocation, mitigation options and costs, and abilities to pass on emissions costs in the jurisdictions.
} 
EU ETS and CA CAT) have applied cap adjustment factors to constrain output-based free allocation in line with declining emissions trajectories.

- In the case of both grandparenting and output-based approaches with fixed output or historically based benchmarks, producers that have taken early action to reduce emissions or output may be disadvantaged relative to those that have not. This can be addressed by using methodologies applying industry-average or best-practice benchmarks. For outputbased approaches, frequent updating of benchmarks based on recent industry performance can disincentivise efficiency improvements by producers.

\section{$3 \quad$ Free allocation in the NZ ETS}

\subsection{Policy history of free allocation}

Since the inception of the NZ ETS under the Climate Change Response (Emissions Trading) Amendment 2008, policy makers have applied two distinct rationales for free allocation, resulting in two methodologies that relate to different types of recipients. The first rationale was to provide compensation to the owners of pre-1990 forest and owners of fishing quota in recognition of the loss of asset value from introducing emissions pricing. This compensation took the form of fixed amounts of free allocation provided in two tranches for forestry (one upon registration over 2010-2012 and one in 2013 [if still eligible ${ }^{4}$ ]) and one tranche for fishing (in 2010). The second rationale was to mitigate the risk of carbon leakage and economic regrets ${ }^{5}$ due to a loss of competitiveness by emissions-intensive and trade-exposed producers as a result of emissions pricing (Ministry for the Environment 2009a,c). This was the rationale applied to the industrial sector (starting in 2010) and agriculture sector (once unit obligations applied). ${ }^{6}$

The design of free allocation to industry and agriculture changed significantly between 2008 and 2009. In the initial NZ ETS design in 2008, the Labour-led government legislated a total starting amount of free allocation for EITE producers (both industrial and agricultural) capped at

\footnotetext{
${ }^{4}$ In 2012, the government introduced "forest offsetting", enabling pre-1990 forest owners to avoid deforestation liabilities if they established a comparable forest elsewhere. Participants who took advantage of this option lost their eligibility to receive the second tranche of free allocation for forestry.

${ }^{5}$ The government characterised "economic regrets" as the loss of business activity that may never return even if it would be competitive once emissions pricing was more widespread internationally. The concept of economic regrets has further dimensions that deserve consideration. Coleman and Kerr (2007) highlight a range of potential economic regrets from subsidising domestic production in the face of uncertainty about the future climate change policies of other countries. Such decisions should reflect consideration of public versus private costs and benefits of the subsidy. They observe that, traditionally, New Zealand typically has not applied domestic tariffs or subsidies in response to overseas tariffs or subsidies because this would lower aggregate welfare.

${ }^{6}$ Agricultural free allocation was scheduled to begin when the sector assumed unit surrender obligations. This was originally scheduled for 2013 and was then deferred first until 2015 and then indefinitely. Under the Climate Change Response (Emissions Trading Reform) Amendment Act 2020, biogenic emissions from agriculture will assume unit obligations no later than 2025 under the NZ ETS or an alternative pricing mechanism.
} 
90 per cent of 2005 emissions per year. This fixed amount was not set to expand for new entrants. The Climate Change Response (Emissions Trading) Amendment Act 2008 did not define the allocation methodology for individual recipients within this amount; this was to be set in later regulations. A linear phase-out for both industrial and agricultural free allocation was planned at 8.3 per cent per year over 2019-2030, meaning no further free allocation would be provided after 2029. The relevant industrial sectors ultimately did not begin unit obligations until mid-2010, and the original plan for free allocation regulations was superseded by the 2009 Act.

Under the Climate Change Response (Moderated Emissions Trading) Amendment Act 2009, passed under a National-led government, the methodology for industry and agriculture changed to an output-based free allocation system based on actual annual output and without an overall limit. As detailed below, key parameters for industrial free allocation were aligned with those of the ETS under development in Australia at the time. This was due to the government's interest in harmonising free allocation across New Zealand and Australia to address trans-Tasman competitiveness and leakage (Ministry for the Environment 2009b,c). Australia accounted for 23 per cent of New Zealand's exports at the time (Ministry for the Environment 2009b). In the 2009 amendments, the level of assistance in each year was to reduce by 1.3 per cent relative to the level in the previous year, starting in 2012 for industrial producers and 2016 for agricultural producers.

The phase-out of industrial free allocation was deferred indefinitely in 2012. The Climate Change Response (Emissions Trading and Other Matters) Amendment Act 2012, passed under a National-led government, provided for a linear reduction in the level of assistance of one per cent per year, to be triggered by an Order in Council after the resumption of a full one-for-one unit obligation in non-forestry sectors. The government announced in 2017 that no change would be made to industrial free allocation before 2021 (Bennett 2017).

In 2019, the Labour-led government introduced the Climate Change Response (Emissions Trading Reform) Amendment Bill (ETR Bill), with the goal of enabling the NZ ETS to better support New Zealand in achieving its domestic and international climate change targets (New Zealand Government 2019). The legislation was passed by Parliament in June 2020. The 2020 Act provides a default pathway for phasing down industrial free allocation over 2021-2050, increases the initial level of free allocation to liable agricultural entities (either processors or farmers) from 90 per cent to 95 per cent, and defers the phase-down of agricultural free allocation indefinitely. The phase-down pathway for industrial free allocation can be adjusted for individual activities through regulation based on advice from the Climate Change Commission. 
The government planned to review further aspects of industrial free allocation starting in 2020 (Cabinet Environment, Energy and Climate Committee 2019). More detail is provided below.

\subsection{Current policy framework for industrial free allocation}

In the NZ ETS, free allocation is provided to eligible EITE industrial producers to help them manage the cost impacts of the NZ ETS, regardless of whether they also hold obligations to surrender units. In fact, most of the free allocation recipients do not have surrender obligations. ${ }^{7}$ This reflects a key design feature of the system: for energy-sector emissions, the obligation to surrender units typically applies upstream, at the level of fossil fuel suppliers or importers. However, large fuel users can opt into a direct unit obligation with a corresponding adjustment to the upstream unit obligation. This approach provides comprehensive coverage of emissions while minimising the administrative burden for both regulators and participants. ${ }^{8}$ Under this framework, no free allocation is provided to fossil fuel producers, which can pass on emissions costs. For most industrial-process emissions, the unit obligation applies directly to emitters, ${ }^{9}$ some of which also qualify for free allocation.

Industrial free allocation is awarded in respect of specific eligible activities, rather than firms, and is technology neutral. ${ }^{10}$ Eligibility involves two determinations: trade exposure and emissions intensity. An activity qualifies as trade exposed unless there is no international trade of the output of the activity across oceans or it is not economically viable to import or export the output of the activity. In New Zealand, electricity generation is deemed explicitly not trade exposed because generators do not have any foreign competition and can pass on the cost of the ETS in the price of electricity. Emissions intensity assessment is based on: (a) the direct emissions from non-energy industrial processes and fossil fuel consumption for stationary energy, ${ }^{11}$ and (b) indirect emissions from electricity consumption. Free allocation is not awarded

\footnotetext{
7 In 2016, among the 85 recipients, only 15 were points of obligation (Ministry for the Environment 2016).

${ }^{8}$ As of June 2019, full coverage of energy and industrial emissions was enabled through 124 mandatory participants (Environmental Protection Authority 2019b).

${ }^{9}$ Exceptions apply for synthetic GHGs. The ETS obligations for sulphur hexafluoride $\left(\mathrm{SF}_{6}\right)$ apply to electrical switchgear operators, and for hydrofluorocarbons (HFCs) and perfluorocarbons (PFCs; excluding PFCs from aluminium) to importers. HFCs in household goods and the effects of passengers entering New Zealand are covered by a levy.

${ }^{10}$ This approach enabled the government to focus assistance on the most emissions-intensive parts of a business and to avoid perverse outcomes regarding how a business is structured (Ministry for the Environment 2009c).

${ }^{11}$ Since the 2008 Act, the scope of "stationary energy" has included direct use of coal, natural gas, waste and used oil combusted in carrying out the activity (including emissions associated with the use of steam generated from these fuels), and emissions from geothermal steam used in carrying out the activity (Ministry for the Environment 2009c). In the 2012 amendments, the scope of allocative baselines was expanded to include fugitive coal seam methane emissions and the direct use of liquid fossil fuels in stationary equipment (Ministry for the Environment 2013).
} 
in respect of transport emissions, nor are transport emissions factored into eligibility assessment. ${ }^{12}$ Further exclusions apply. ${ }^{13}$

The determination of indirect electricity emissions is complex in the NZ ETS. Different methods are used for assessing initial eligibility for free allocation versus calculating the actual amount of free allocation. In the New Zealand electricity market, which on average currently operates with more than 80 per cent renewable generation through an integrated national grid, the electricity price is set by the marginal generator, which commonly uses fossil fuels when demand exceeds renewable supply. To compensate ETS participants for increased electricity prices due to emissions pricing, the government applies a marginal - rather than average - grid emission factor based on a modelled projection for fossil fuel generation. For context, the 2018 average emissions intensity for electricity generation across the grid was $0.1 \mathrm{tCO}_{2} \mathrm{eq} / \mathrm{MWh}$ (Ministry of Business, Innovation and Employment 2020). For calculating actual free allocation, the electricity allocation factor (EAF) applied to most participants ${ }^{14}$ was $0.52 \mathrm{tCO}_{2} \mathrm{eq} / \mathrm{MWh}$ over 2010-2012 and 0.537 tCO 2 eq/MWh over 2013-2020. As a result, the number of New Zealand Units (NZUs) issued in respect of electricity consumption by free allocation recipients has exceeded the number of NZUs received by the government for the corresponding amount of electricity production. The EAF influences a significant component of the government's unit liability under the NZ ETS; in 2018, electricity use accounted for about one-third of industrial free allocation, excluding aluminium smelting (Ministry for the Environment 2019d). ${ }^{15}$

In contrast, the test to assess eligibility to receive free allocation applies an electricity emission factor of $1 \mathrm{tCO}_{2} \mathrm{eq} / \mathrm{MWh} .{ }^{16}$ For reasons of trans-Tasman competitiveness, as discussed above, this value was taken from the industrial free allocation methodology applied in the Australian ETS under development at the time (Australian Department of Climate Change 2008b). ${ }^{17}$ This high value reflected the dominance of coal-fired generation in Australia, which was and remains inconsistent with the New Zealand context.

\footnotetext{
12 During the 2009 amendment process, the government concluded that including transport emissions in eligibility assessment and allocative baselines would complicate and prolong determinations and generally would not make a material difference to emissions intensity outcomes (Ministry for the Environment 2009b).

${ }^{13}$ Beyond the transport of inputs and outputs, the following exclusions apply to the scope of industrial free allocation: extraction or production of raw materials used in the activity; complementary activities (e.g. packaging, head office, administrative and marketing); on-site electricity generation; all forestry operations (including establishment, maintenance, and harvesting); the production of wood chips; the collection, sorting, and baling of recovered paper for use in the activity; further processing, cutting or colouring of tissue paper rolls; and the generation of steam for use outside the activity (Ministry for the Environment 2009c).

${ }^{14} \mathrm{~A}$ unique EAF applies to the Tiwai Point Aluminium Smelter due to the nature of its electricity contracts.

${ }^{15}$ Aluminium smelting is excluded from this calculation due to the nature of its electricity contracts.

${ }^{16}$ Climate Change (Eligible Industrial Activities) Regulations 2010, section 6(b).

${ }^{17}$ This was the Australian Carbon Pollution Reduction Scheme (CPRS), which never entered into force. Its successor, the Australian Carbon Pricing Mechanism (CPM), operated from 2012 to 2015.
} 
The emissions intensity variable for eligibility to receive free allocation is expressed in tonnes of $\mathrm{CO}_{2}$ eq emissions per million dollars of revenue from output sales. The emissions intensity variable is calculated for each industrial activity based on the historical average across the whole industry over a specified period (2006/2007 to $2008 / 2009$ for most firms ${ }^{18}$ ) and accounts for both direct and indirect emissions. Two eligibility thresholds apply: moderately intensive sectors have an emissions intensity of 800-1,600 $\mathrm{tCO}_{2} \mathrm{eq} /$ million NZD revenue, and highly intensive sectors have an emissions intensity of at least 1,600 $\mathrm{tCO}_{2} \mathrm{eq} / \mathrm{million} \mathrm{NZD}$ revenue. These thresholds were derived from those initially proposed for Australia's Carbon Pollution Reduction Scheme (CPRS), with adjustment for exchange rates but not for the relative emissions intensity of electricity generation in New Zealand (Ministry for the Environment 2009b).

Table 1 presents the 26 industrial sectors eligible for free allocation in the NZ ETS according to their emissions intensity category. It is interesting to note that the production of some horticultural products qualifies for industrial free allocation. This is due to space heating requirements in greenhouses. Free allocation with respect to the production of animals and animal products and the use of synthetic fertilisers is classified as agricultural free allocation.

Table 1: Eligible activities for free allocation in the NZ ETS

$\begin{array}{ll}\text { Emissions intensity category } & \text { Eligible activity } \\ \text { Highly intensive } & \text { Aluminium smelting } \\ & \text { Iron and steel } \\ & \text { Manufacture of carbon steel from cold ferrous feed } \\ & \text { Production of burnt lime } \\ & \text { Production of carbamide (urea) } \\ & \text { Production of cartonboard } \\ & \text { Production of caustic soda } \\ & \text { Production of cementitious products } \\ & \text { Production of cut roses } \\ & \text { Production of hydrogen peroxide } \\ & \text { Production of market pulp } \\ & \text { Production of methanol } \\ & \text { Production of newsprint } \\ & \text { Production of packaging and industrial paper }\end{array}$

${ }^{18}$ New entrants in new sectors can be accommodated. 


\section{Emissions intensity category}

Moderately intensive

\author{
Eligible activity \\ Production of clay bricks and field tiles \\ Production of ethanol \\ Production of fresh tomatoes \\ Production of fresh capsicums \\ Production of fresh cucumbers \\ Production of gelatine \\ Production of glass containers \\ Production of lactose \\ Production of protein meal \\ Production of reconstituted wood panels \\ Production of tissue paper \\ Production of whey powder
}

Source: Adapted from Environmental Protection Authority (2019a)

Once eligibility has been determined, the actual amount of free allocation (FA) distributed to a company each year depends on three variables: the quantity of output $(0)$, the allocative baseline $(A B)$, and the assistance factor $(A F) .{ }^{19}$

\section{$F A=0 \times A B \times A F$}

Free allocation recipients receive a provisional quantity of units based on the output during the previous year, and this amount is adjusted in the subsequent year when the actual level of production has been reported. The assistance factor is initially set at 60 per cent for moderately intensive activities and 90 per cent for highly intensive activities. As with assessing eligibility, the emissions intensity variable for providing free allocation is calculated for each industrial activity based on the historical average across the whole industry over a specified period (2006/2007 to $2008 / 2009$ for most firms ${ }^{20}$ ) and accounts for both direct emissions and indirect emissions from purchasing electricity. There are 44 allocative baselines corresponding to the 44 eligible products.

\subsection{Profile of industrial free allocation through 2020}

To date, the amount of industrial free allocation in the NZ ETS has been relatively small compared to the annual surrender volume. In FY 2020-2021, ${ }^{21} 7.1$ million NZUs were allocated for free, equivalent to 18 per cent of the surrender volume of 38.9 million units (Environmental Protection Authority 2021a). This compares to industrial free allocation of 8.4 million NZUs in FY

\footnotetext{
19 In section 81 of the Climate Change Response Act 2002, the term "level of assistance (LA)" is used rather than "assistance factor (AF)", and the "amount of the prescribed product (PDCT)" is used rather than "output (O)".

${ }^{20}$ New entrants in new sectors can be accommodated.

${ }^{21}$ For NZ ETS reporting, the financial year extends from July to June.
} 
2019-2020, which was nearly 21 per cent of the surrender volume of 40.3 million units. Figure 1 shows the progression of industrial free allocation over time on a calendar-year basis. This figure should be interpreted in the context of the changing levels of free allocation as the unit obligation progressed from 50 per cent (one unit for every 2 tonnes of emissions) over 20102016 to 67 per cent (one unit for every 1.5 tonnes of emissions) in 2017, 83 per cent (one unit for every 1.2 tonnes of emissions) in 2018, and 100 per cent (one unit per tonne of emissions) in 2019 and beyond.

Figure 1: Trends in industrial free allocation in the NZ ETS: 2010 to 2018

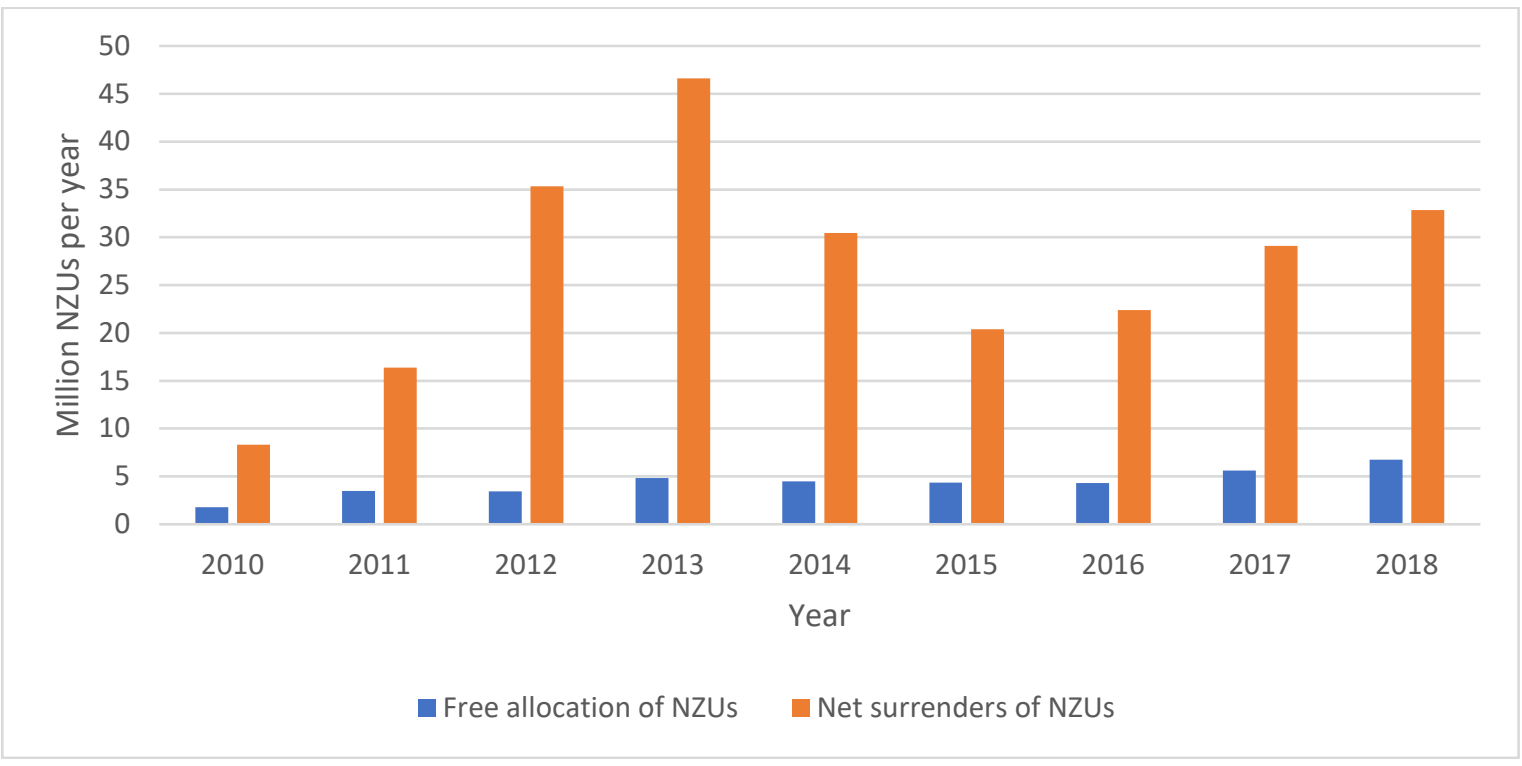

Source: Environmental Protection Authority (2019c)

It is challenging to assess the monetary value of industrial free allocation to the government and to recipients. When the government issues free allocation or receives surrendered units, it records a debit or credit (respectively) based on the market price of units at the time. For budget management purposes, the government periodically assesses its ETS net position (Controller and Auditor-General 2011). Some recipients will have received industrial free allocation valued at a low market price initially, and then banked it for later sale or surrender at a higher market price. Figure 2 presents estimates of the nominal market value of industrial free allocation at the time of issuance using an average NZU market price for that year. The trend line for market value reflects the drop and then recovery of NZU prices over time. The market price of NZUs hit an all-time low of NZ\$1.45 in February 2013. 
Figure 2: Estimated market value of industrial free allocation in the NZ ETS: 2010 to 2018

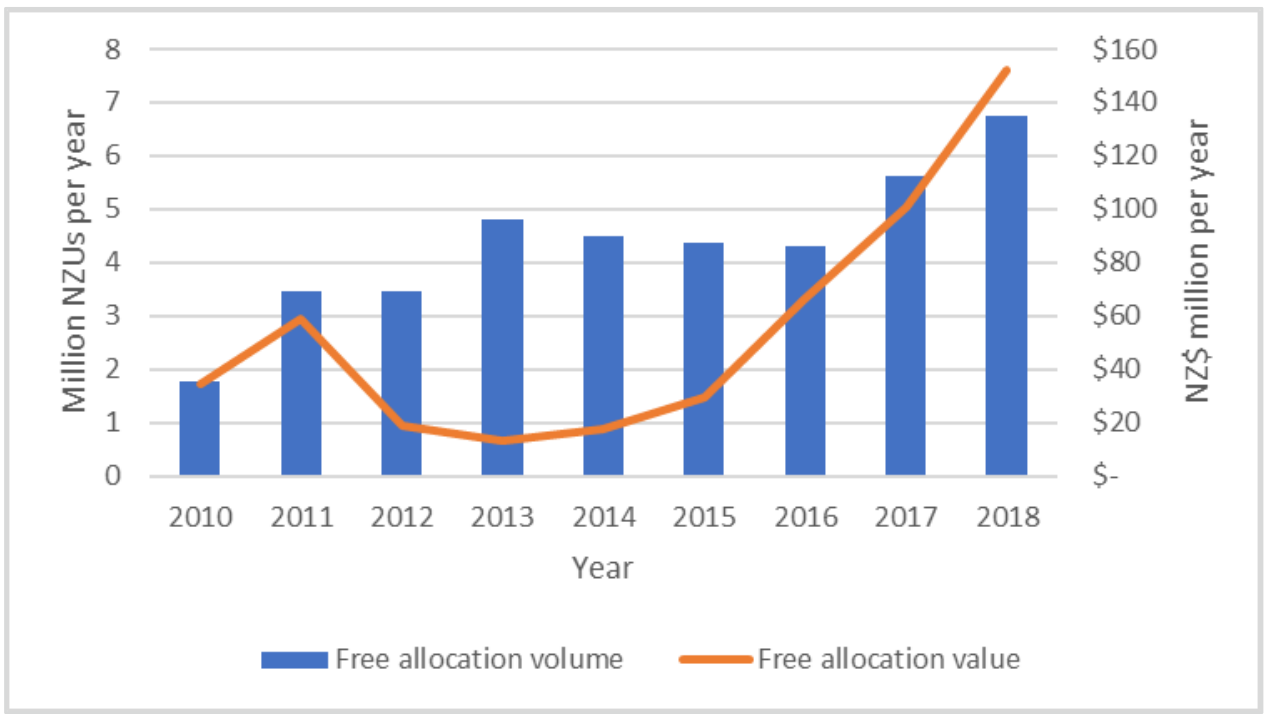

Source: Allocation data from Environmental Protection Authority $(2018,2019$ c); NZU price data from OM Financial (now Jarden). Note: The average NZU price was calculated based on recorded spot prices for NZUs in each year from January 2010 through November 2018. These have not been weighted by the volume of unit sales at each price or adjusted for inflation.

The amount of free allocation in the NZ ETS is highly concentrated among participants. Figure 3 profiles the distribution of free allocation in 2018. In that year, four of 85 eligible companies together accounted for almost 70 per cent of total free allocation: New Zealand Steel Development Limited, New Zealand Aluminium Smelters Limited, Methanex New Zealand Limited, and Fletcher Concrete and Infrastructure Limited (Environmental Protection Authority 2019a). Only 6 per cent of industrial free allocation went to moderately intensive producers.

In a report drawing from both government and independent studies to help inform government decisions on NZ ETS reform, Sense Partners (2018) found the NZ ETS had not impacted significantly on the competitiveness of EITE producers to date. ${ }^{22}$ However, emission prices were very low for a long period and EITE producers received considerable free allocation. The report noted uncertainty about the future impact of emissions pricing under rising domestic emission prices and declining levels of free allocation, alongside uneven target ambition and emissions pricing in other jurisdictions under the Paris Agreement. The analysis by Sense Partners suggested that while many industrial producers could absorb rising emission costs with reduced profitability if unable to pass them on, some (notably primary metals, cement, and mining) could be highly sensitive to even modest emission prices. Among those examined, Sense

\footnotetext{
${ }^{22}$ According to Sense Partners (2018), "The analysis suggests New Zealand firms have faced effective costs of emissions that are not very high by international standards but have been high compared with those of our major trading partners in the Asia Pacific region. That said, on all main indicators of competitiveness effects (profits, output, employment, and trade) there is no perceptible evidence of negative effects of existing climate policy on emissions intensive and trade exposed industries."
} 
Partners identified the following sectors as facing the biggest risks of leakage: steel, cement, aluminium, and petrochemicals (methanol and urea). 
Figure 3: Percentage of NZUs freely allocated by activity (2018)

\begin{tabular}{|l|l|l|l} 
- Iron, steel, and aluminium manufacturing (3 recipients) \\
- Market pulp, tissue paper, packaging and industrial paper, newsprint, \\
and cartonboard manufacturing (7 recipients) \\
- Methanol, ethanol, and hydrogen peroxide (3 recipients) \\
- Clay bricks and field tiles, cementitious products, and burnt lime (3 \\
recipients) \\
- Production of ammonia-urea, caustic soda, glass containers, and \\
gelatine (4 recipients) \\
- Meat by-product rendering (16 recipients)
\end{tabular}

Source: Data from Environmental Protection Authority $(2019 a, c)$ 


\subsection{Outlook for industrial free allocation post-2021}

The policy framework for free allocation has changed under the Climate Change Response (Emissions Trading Reform) Amendment Act 2020. The default level of assistance for industrial free allocation will be reduced by 0.01 in each year over 2021-2030, 0.02 in each year over 2031-2040, and 0.03 in each year over 2041-2050. By 2050, only highly emissions-intensive activities will continue to receive free allocation, with a level of assistance of 0.3 (30 per cent). Through regulations, the government could decrease or increase the rate of change for individual activities following advice from the Climate Change Commission as follows:

- The commission must recommend that a decreased phase-out rate should be set for one or more eligible industrial activities if it is satisfied that there is an ongoing and substantial risk that activities will be relocated outside of New Zealand to reduce emissions-related costs. No decrease can apply before 1 January 2031, and the decision must be made before the start of the year in which the change will apply. The rate of reduction for the assistance factor must be at least one percentage point per year over 2031-2040 and two percentage points per year over 2041-2050.

- The commission may recommend that an increased phase-out rate should be set for one or more eligible industrial activities if it is satisfied that it is appropriate to do so, having regard to a list of matters guiding Ministerial decisions in section $84 C(3)$. An increase can apply in any emissions budget period from 1 January 2026. The decision must be made before the start of an emissions budget period, but may be revised during the budget period if the emissions budget has been revised or there has been a major change in assumptions.

When deciding to issue or amend regulations that increase or decrease the phase-out rate for industrial free allocation, the Minister must consider the following matters:

(a) any targets or budgets set for reducing emissions of greenhouse gases; and

(b) New Zealand's nationally determined contributions under the Paris Agreement; and

(c) the level of risk of emissions leakage (increased emissions overseas as a result of emissions reductions in New Zealand, for example, an activity being relocated outside of New Zealand to reduce the emissions-related costs for the activity), based on -

(i) the emissions-related costs and policies in competing jurisdictions; and

(ii) the markets for international trade in the products produced by the activity; and

(iii) the ability of affected eligible persons to pass on increased costs to customers; and

(d) the risk that the value of the allocation for the activity will exceed the cost of meeting the emissions trading scheme obligations in relation to the activity; and

(e) other sources of supply into the emissions trading scheme, including offshore emissions reductions; and 
(f) the availability of low-emission technologies related to the activity; and

(g) international climate change obligations; and

(h) the proper functioning of the emissions trading scheme; and

(i) the cost to the taxpayer of providing allocations for the activity; and

(j) the recommendations made by the Climate Change Commission under section 5ZOB; and

(k) any other matters that the Minister considers relevant (section 84C[3]).

Under the 2020 Act's default option for the agriculture sector, the level of assistance for outputbased free allocation is set to begin at 95 per cent (instead of the previous 90 per cent) and the phase-down is suspended indefinitely. Under an alternative mechanism for agricultural emissions pricing to be presented by Ministers for consideration in 2022, decisions on what assistance, if any, should be given to participants would be informed by advice from the Climate Change Commission.

Pursuant to the $2020 \mathrm{Act}$, in mid-2020 the government projected demand for industrial free allocation of approximately 43 million units over 2021-2025 (Ministry for the Environment 2020b), which would average 8.6 million units per year. This was based on "a combination of an individual assessment of the likely emissions projections for the largest four emitters, ${ }^{23}$ and 1 per cent growth in emissions for the remaining aggregated businesses based on estimated increases in production levels" (Ministry for the Environment 2019c). It reflected the legislated phase-out rate of 1 per cent per year starting in 2021. These calculations assumed that the government retained the same eligibility criteria and allocative baselines currently specified in legislation and regulation. Those projections pre-dated the announcements that New Zealand Aluminium Smelters Limited expects to close after December 2024 (Rio Tinto 2021) and Refining NZ will convert from an oil refinery to a fuel import terminal from mid-2022 (Refining NZ 2021). They also predated the impacts of the COVID-19 pandemic.

In August 2021, the government announced updates to supply settings in NZ ETS regulations (Ministry for the Environment 2021c). The results implied an adjustment in projected industrial free allocation over 2021-2025 from 43 million units to 40 million units. It also implied cumulative industrial free allocation over 2021-2026 of 46 million units, which would be worth NZ\$2.3 billion at a sample price of NZ\$50 per unit.

\footnotetext{
${ }^{23}$ These consist of New Zealand Steel, New Zealand Aluminium Smelters, Methanex, and Refining NZ. Refining NZ has been exempted to date from free allocation under the terms of a negotiated greenhouse agreement (NGA), which will conclude in 2022. The projections account for both units issued under the NGA pre-2023 and projected free allocation post-2022 (Ministry for the Environment 2019c). The projections do not reflect the conversion of Refining NZ to a fuel import terminal from mid-2022 (Refining NZ 2021).
} 


\section{$4 \quad$ International experience with free allocation}

This section details free allocation in the ETSs of the European Union and California. It also examines the approach in Australia's CPM, which is no longer operational.

\subsection{European Union Emissions Trading System (EU ETS)}

The EU ETS started in 2005 with around 11,000 installations in the energy and industrial sectors and covered 45 per cent of the total greenhouse gas emissions of the European Union (EU) (European Commission 2019a). The programme is now in Phase III (2013-2020) and operates with a cap reduction rate of 1.74 per cent per year. The EU ETS works with two kinds of unit allocation: auctioning and free allocation (European Commission 2015). Only direct emissions by entities with obligations to surrender allowances are eligible for free allocation. Each year, all obligated entities receive a percentage of free allocation and must purchase the other part by auction, with the exception of electricity producers, which have to purchase the totality of their allowances at auction. ${ }^{24}$ For non-EITE participants, 80 per cent of units were freely allocated in 2013, with a phase-down to 30 per cent in 2020 (Table 2). For Phase III, EITE participants received 100 per cent of their benchmarked entitlement to free allocation (discussed below), plus financial compensation for the increase in electricity prices induced by the EU ETS. The EU ETS maintains a new entrant reserve in each phase, which makes units available for free allocation to installations that are new or that significantly increase their capacity.

Table 2: Assistance factor (AF) for non-EITE industrial sectors

\begin{tabular}{|l|cccccccc|}
\hline Year & 2013 & 2014 & 2015 & 2016 & 2017 & 2018 & 2019 & 2020 \\
\hline $\begin{array}{l}\text { AF for non-EITE } \\
\text { sectors }\end{array}$ & $80 \%$ & $72.9 \%$ & $65.7 \%$ & $58.6 \%$ & $51.4 \%$ & $44.2 \%$ & $37.1 \%$ & $30 \%$ \\
\hline
\end{tabular}

Source: European Commission (2015)

For Phase III, all entities received their free allocation (FA) based on the following equation (European Commission 2015):

$$
\mathrm{FA}=0 \times \mathrm{Bm} \times \mathrm{AF} \times \mathrm{CSCF}
$$

Where:

O = quantity of output for one fixed year (2005-2008 median or 2009-2010 median)

$\mathrm{Bm}=$ benchmark factor

AF = assistance factor ( 80 per cent in 2013, decreasing each year to 30 per cent in 2020 for nonEITE participants, 100 per cent for EITE participants, and 0 per cent for electricity generators)

CSCF $=$ cross-sectoral correction factor

\footnotetext{
${ }^{24}$ In Phase III, an exception applied for eligible member states that have received transitional free allocation to assist with modernisation of their electricity sector (European Commission 2015).
} 
The output basis for allocation in the EU ETS was not updated and was set according to output in 2005-2008 or 2009-2010. To link the current output with the output basis, four categories of allocation were used (Partnership for Market Readiness and International Carbon Action Partnership 2016):

- If the current output was less than 10 per cent of the historical basis, the firm did not receive free allocation in the following year.

- If the current output was between 10 per cent and 25 per cent of the historical basis, the output basis was adjusted at 25 per cent for the following year.

- If the current output was between 25 per cent and 50 per cent of the historical basis, the output basis was adjusted at 50 per cent for the following year.

- If the current output was more than 50 per cent of the historical basis, the output basis stayed at the full historical amount for the following year.

Benchmark factors have been calculated from the average direct emissions per unit of output of the top 10 per cent most efficient entities of each sector. Regulators have developed 52 specific product-based benchmarks (European Commission 2019b). For the products without specific product-based benchmarks, free allocation is based on an energy-based benchmark estimated from heat production or fuel consumption. Unlike the allocative baseline in the NZ ETS, benchmark factors in the EU ETS cover only direct emissions since indirect emissions are not eligible for free allocation.

The cross-sectoral correction factor is a coefficient that ensures the quantity of free allowances for industrial entities does not exceed the limit set for the phase. It is calculated by comparing the sum of the preliminary total annual amount of free allocation submitted by member states to the limit. For electricity generators, a linear reduction factor was used that exactly corresponds to the decreasing cap rate of 1.74 per cent for Phase III (Table 3).

Table 3: Linear reduction factor (LRF) and cross-sectoral correction factor (CSCF) for Phase III of the EU ETS

\begin{tabular}{|l|cccccccc|}
\hline Year & $\mathbf{2 0 1 3}$ & $\mathbf{2 0 1 4}$ & $\mathbf{2 0 1 5}$ & $\mathbf{2 0 1 6}$ & $\mathbf{2 0 1 7}$ & $\mathbf{2 0 1 8}$ & $\mathbf{2 0 1 9}$ & $\mathbf{2 0 2 0}$ \\
\hline LRF & 1 & 0.9826 & 0.9652 & 0.9478 & 0.9304 & 0.913 & 0.8956 & 0.8782 \\
CSCF & 0.9427 & 0.9263 & 0.9098 & 0.893 & 0.8761 & 0.859 & 0.8417 & 0.8244 \\
\hline
\end{tabular}

Source: (European Commission 2015)

The assistance factor reflects carbon leakage risk in a sector of production and is estimated by assessing trade exposure (the non-EU trade intensity) and the change in production cost due 
to the EU ETS (accounting for direct and indirect costs as a percentage of total gross value added).

Trade exposure (TE) is calculated using the following equation (European Commission 2015):

$$
\begin{aligned}
\mathrm{TE}= & \text { (extra-EU ETS exports + extra-EU ETS imports) / } \\
& \text { (EU ETS production + extra-EU ETS imports) }
\end{aligned}
$$

The change in production cost due to the ETS is calculated using the following equation (European Commission 2015):

\section{ETS cost $=$ (direct emissions $\times$ auctioning factor + indirect emissions $) \times \mathrm{CO}_{2}$ eq price $/$ GVA} Where:

Direct emissions = emissions of the sector in 2012

Auctioning factor $=80$ per cent in 2013, decreasing to 30 per cent in 2020

Indirect emissions = electricity consumption $\times$ emission factor $\left(\mathrm{EF}=0.465 \mathrm{tCO}{ }_{2} \mathrm{eq} / \mathrm{MWh}\right)$

$\mathrm{CO}_{2}$ price $=$ estimated at $€ 30$ as an average for the 2013-2019 period

GVA = gross value added

From these two variables, a quantitative assessment is used to determine carbon leakage risk for the sector. For Phase III, any of three criteria could be used to confirm carbon leakage risk as follows:

- The ETS cost was at least 5 per cent of the GVA and the sector's non-EU trade intensity was above 10 per cent.

- The ETS cost was at least 30 per cent of the GVA.

- The sector's non-EU trade intensity was above 30 per cent.

If a sector was close to the quantitative threshold but did not reach it, a qualitative assessment was conducted. The European Commission applied three criteria:

- The extent to which it was possible for installations in the sector to reduce their GHG emissions or electricity consumption through additional investment

- The current and projected market characteristics of the sector, such as the market concentration, homogeneity of the product, competitive position relative to non-EU producers, and bargaining power of the sector in the value chain

- Profit margins of the sector as an indicator of the ability to absorb costs and long-run investment or relocation decisions. 
A first list of sectors and subsectors at significant risk of carbon leakage (referred to as the "carbon leakage list") was determined for the years 2013 and 2014, and a second for the rest of Phase III (2015-2020).

The EU ETS also included an assistance scheme for industries facing a cost increase due to indirect emissions from electricity. This monetary assistance was provided directly through member state aid. Whereas each member state was free to decide about giving this assistance and its level, the European Commission set the eligibility criteria and the equation for aid allocation. A sector was eligible for financial compensation if the indirect emissions cost was at least 5 per cent of the GVA and the sector's non-EU trade intensity was above 10 per cent, or if it met all of the following criteria:

- $\quad$ The indirect emissions cost was at least 2.5 per cent of the GVA

- The sector's non-EU trade intensity was at least 25 per cent and there was evidence the sector could not pass on the cost of indirect emissions

- Benchmarking showed fuel and electricity substitutability for at least part of the sector.

The European Commission published guidelines with the list of the 15 eligible sectors for financial assistance (which also were eligible for free allocation) and the methodology for aid allocation. The maximum level of financial assistance a member state could provide (Amaxt) was set by the following equation (European Commission 2012):

\section{$A \max _{t}=A i_{t} \times C_{t} \times P_{t-1} \times E \times B O$}

Where:

$A \mathbf{i}_{\mathbf{t}}=$ the maximum aid intensity allowed by the EU ETS for the current year ${ }^{25}$

$\mathbf{C}_{\mathbf{t}}=$ the electricity emission factor specific to different areas reflecting the local energy mix at the current year

$\mathbf{P}_{\mathbf{t}-\mathbf{1}}=$ the allowance price in the previous year

$\mathbf{E}=$ the product-specific electricity consumption efficiency benchmark

BO = baseline output

As for free allocation, the output basis for monetary assistance was not updated in Phase III.

As currently legislated, Phase IV (2021-2030) of the EU ETS has introduced some changes to free allocation (European Commission 2021b,d; International Carbon Action Partnership 2021). The annual cap reduction rate has increased to 2.2 per cent. The methodology for assessing carbon leakage risk has changed to apply a composite indicator reflecting trade and emissions intensity as follows:

\footnotetext{
25 Its level decreased during Phase III of the EU ETS from 85 per cent between 2013 and 2015, to 80 per cent between 2016 and 2018 and 75 per cent in 2019 and 2020
} 
- $\quad$ Trade intensity $\times$ emissions intensity $>0.2$

- Trade intensity $\times$ emissions intensity $>0.15<0.2$ (this triggers qualitative assessment based on abatement potential, market characteristics, and profit margins).

Sectors at high risk of carbon leakage will continue to receive 100 per cent of the benchmarked amount of free allocation and financial compensation for the cost of indirect emissions. For less exposed sectors, free allocation will be provided at a level of 30 per cent until 2026 and phased out by 2030. The carbon leakage list for Phase IV was adopted in February 2019 and will be updated every five years. Two updates are also scheduled for benchmark values. Benchmark values will be subject to an annual reduction rate (0.2-1.6 per cent) to account for technological progress. Finally, the free allocation system will be based on output values that can be updated annually with an adjustment threshold of 15 per cent. The EU ETS is budgeting 6 billion units of free allocation for the 10 years coved by Phase IV, compared to 6.5 billion units for the eight years covered by Phase III.

In July 2021, the European Commission released its "Fit for 55" proposal, which, if introduced, would make further changes to carbon leakage measures in the second half of Phase IV of the EU ETS (European Commission 2021c). The annual cap reduction would increase from 2.2 per cent to 4.2 per cent. Free allocation to the aviation sector would be phased out by 2027 . The reduction rates for free allocation benchmarks would increase from 2026 . Free allocation would become conditional on implementation of cost-efficient mitigation measures as recommended in energy audits; failure to do so would reduce free allocation by 25 percent. Changes would enable low-carbon or zero-carbon technologies to benefit from free allocation. A carbon border adjustment mechanism (CBAM; detailed later in the paper) would take effect from 2026, alongside a phase-out of free allocation for CBAM sectors by 2035 (European Commission 2021a).

\subsection{California Cap-and-Trade Program}

The California Air Resources Board (CARB) began compliance obligations under the CA CAT in 2013. The programme is in Phase III (2018-2020) and covers around 80 per cent of California's GHG emissions (International Carbon Action Partnership 2019). More than 500 entities are liable to surrender allowances. The system covers large industrial processes, electricity generation, electricity imports, other stationary combustion, natural gas suppliers, and other liquid fuels suppliers. During Phase III, the cap is decreasing by 3.3 per cent each year and allowances are allocated through a mix of auctioning and free allocation. 
There are two kinds of free allocation. First, industrial facilities receive free allocation as a support to prevent carbon leakage. Second, electricity distributors and natural gas suppliers receive free allocation on behalf of ratepayers. These installations must sell their freely allocated allowances in the auctioning platform and use this income to benefit the ratepayers.

The industrial free allocation scheme calculates unit entitlements using the following equation (California Air Resources Board 2019):

Where:

$$
F A_{t}=O_{t-2} \times B m \times A F \times C_{t}
$$

$\mathbf{O}_{\mathbf{t}-\mathbf{2}}=$ quantity of output in the year $\mathrm{t}-2$ (the quantity of free allowances is adjusted when the actual quantity of output is known)

$\mathrm{Bm}=$ benchmark factor

$\mathbf{A F}=$ assistance factor

$\mathbf{C}_{\mathrm{t}}=$ cap adjustment factor

The benchmark factor is a sector-specific benchmark. The programme applies 32 product-based benchmarks (California Air Resources Board 2019). When a product eligible for free allocation does not correspond to a specific product-based benchmark, an energy-based benchmark applies. This factor corresponds to 90 per cent of the average emissions by the sector. However, if 90 per cent of the sector average is more stringent than emissions by any facility in the sector, the benchmark factor is set according to the "best-in-class" value (the emission intensity of the most efficient facility). Like the allocative baseline in the NZ ETS free allocation equation, the benchmark factor accounts for both direct and indirect emissions. Standard emission factors apply for heat consumption (0.0663 $\left.\mathrm{tCO}_{2} / \mathrm{MMBtu}\right)$ and electricity consumption (0.431 $\mathrm{tCO}_{2} / \mathrm{MWh}$ ) (California Air Resources Board 2011).

The cap adjustment factor is a coefficient that reflects the cap reduction rate (Table 4). The value is higher for nitrogenous fertiliser manufacturing, cement manufacturing and lime manufacturing, which are activities with more than 50 per cent of total emissions from process emissions, a high emissions intensity, and a high leakage risk classification.

Table 4: Cap adjustment factor between 2013 and 2020 in the California Cap-and-Trade Program

\begin{tabular}{|l|llllllll|}
\hline Year & $\mathbf{2 0 1 3}$ & $\mathbf{2 0 1 4}$ & $\mathbf{2 0 1 5}$ & $\mathbf{2 0 1 6}$ & $\mathbf{2 0 1 7}$ & $\mathbf{2 0 1 8}$ & $\mathbf{2 0 1 9}$ & $\mathbf{2 0 2 0}$ \\
\hline Standard activities & 0.981 & 0.963 & 0.944 & 0.925 & 0.907 & 0.888 & 0.869 & 0.851 \\
Highly intensive & 0.991 & 0.981 & 0.972 & 0.963 & 0.953 & 0.944 & 0.935 & 0.925 \\
\hline
\end{tabular}

Source: California Air Resources Board (2019) 
Carbon leakage risk is assessed based on trade exposure and emissions intensity. Trade exposure (TE) is calculated with the following equation (California Air Resources Board 2013):

$$
\mathrm{TE}=\text { (exports }+ \text { imports) / (shipments }+ \text { imports) }
$$

CARB applies three categories of trade exposure:

- High - up to 19 per cent

- Medium - between 19 per cent and 10 per cent

- Low - below 10 per cent.

Emissions intensity (EI) is calculated with the same method as in the NZ ETS:

$$
\mathrm{EI}=\text { metric tonnes } \mathrm{CO}_{2} \mathrm{eq} / \text { million USD value added }
$$

CARB established four categories of emissions intensity:

- High - up to 5,000 $\mathrm{tCO}_{2} \mathrm{eq} /$ million USD value added

- Medium -4,999-1,000 $\mathrm{tCO}_{2}$ eq/million USD value added

- Low - 999-100 tCO $_{2}$ eq/million USD value added

- Very low - less than $100 \mathrm{tCO}_{2} \mathrm{eq} /$ million USD value added.

From these two variables, CARB initially proposed to establish a variable assistance factor according to carbon leakage risk (Table 5) (California Air Resources Board 2010). Ultimately, the legislation applied the same assistance factor (100 per cent) for all categories of leakage risk (California Air Resources Board 2018). The list of sectors at risk of carbon leakage is published in the Regulation for the California Cap on Greenhouse Gas Emissions and Market-Based Compliance Mechanisms for the current phase (2018-2020) and the forthcoming phase (20212030). For the post-2020 period, the CA CAT will continue with 100 per cent free allocation for eligible activities and there is no proposal to update benchmark factors. The most relevant change to come in the next phase is increasing the cap reduction rate to 4.1 per cent per year. 
Table 5: Carbon leakage risk categories from the California Air Resources Board

$\begin{array}{ccc}\text { Leakage risk } & \text { Emissions intensity } & \begin{array}{c}\text { Trade exposure } \\ \text { High }\end{array} \\ & \text { High } & \begin{array}{c}\text { High } \\ \text { Medium } \\ \text { Low }\end{array} \\ & \text { Medium } & \text { High } \\ & \text { Medium } & \text { Medium } \\ \text { Medium } & & \text { Low } \\ & \text { Low } & \text { High } \\ & \text { Low } & \text { Medium } \\ & & \text { Low } \\ \text { Low } & \text { Very low } & \text { High } \\ & & \text { Medium } \\ & & \text { Low }\end{array}$

Source: California Air Resources Board (2013)

\subsection{Australian Carbon Pricing Mechanism (CPM)}

In the course of designing its system for national emissions trading (first the CPRS and then the CPM), Australia developed a methodology for industrial free allocation. In relation to the CPM over 2011-2012, Australia defined eligible sectors for industrial assistance under the Jobs and Competitiveness Program (JCP) (Part 7 - Clean Energy Act 2011). The JCP aimed to reduce the risk of carbon leakage and assist companies with transitioning into emissions trading (Office of Parliamentary Counsel 2013). Within the JCP, the industrial assistance consisted of distributing free allocation to eligible participants. In the CPM, the basic equation for free allocation was the same as in the NZ ETS, with an assistance factor that varied according to the emissions intensity category. No cap applied to allowance distribution, but the JCP included a carbon productivity contribution that corresponded to a phase-out rate for the assistance factor of 1.3 per cent per year.

In the eligibility assessment under the CPM, emissions intensity was defined as the average emissions from the activity per Australian million dollars of revenue or per million Australian dollars of value added. A sector was considered highly emissions intensive if the level of emissions intensity was at least $2,000 \mathrm{tCO}_{2} \mathrm{eq} /$ million AUD revenue or $6,000 \mathrm{tCO}_{2} \mathrm{eq} / \mathrm{million}$ AUD value added. A sector was considered moderately emissions intensive if the level of emissions intensity was $1,000-1,999 \mathrm{tCO}_{2} \mathrm{eq} / \mathrm{million}$ AUD revenue or $3,000-5,999 \mathrm{tCO}_{2} \mathrm{eq} / \mathrm{million}$ AUD value added. The electricity allocative factor used to estimate past emissions intensity and set the allocative baseline was $1 \mathrm{tCO}_{2} \mathrm{eq} / \mathrm{MWh}$. Trade exposure was assessed using a 
quantitative and qualitative test. The quantitative level of trade exposure was calculated using the ratio of value of imports and exports to the value of domestic production. The qualitative assessment determined if the sector had the capacity to pass on the cost of emissions pricing or not. If the quantitative trade exposure ratio was higher than 10 per cent and the sector was not considered able to pass on the emission cost to consumers, the sector was considered trade exposed (Commonwealth of Australia 2012).

It is interesting to observe how the Australian government's position evolved between its Green and White Papers on the CPRS. In the Green Paper, the government initially proposed defining the emissions intensity metric using only revenue rather than value added. The rationale was that revenue constituted a more transparent, well-understood, and comparable indicator. The government observed:

\footnotetext{
Value add measures could also lead to firms with very small emissions liabilities but small value add being eligible for assistance. Measures based on value add can be highly volatile and very sensitive to the particular estimation method ... The main disadvantage of the use of revenue as the common measure is that this would result in lower measured emissions intensities for activities that have more significant input costs (such as those further down the supply chain) and for industries that require a higher return on their capital. If emissions-intensive activities tend to occur early in the supply chain and if the most emissions-intensive activities are highly capital-intensive, this would be a lesser concern. (Australian Department of Climate Change 2008b)
}

Following consultation, this changed in the White Paper, which offered participants the choice between revenue and value-added metrics (Australian Department of Climate Change 2008a).

The Green Paper provided a preliminary rationale for setting the threshold values for emissions intensity. Based on industrial production data for 2001-2002, the government found that the average emissions per unit of revenue of all industry sectors was $348 \mathrm{tCO}_{2} \mathrm{eq} / \mathrm{million}$ AUD revenue and observed step changes in emissions intensity between groups of producers at around 2,000 $\mathrm{tCO}_{2} \mathrm{eq} / \mathrm{million} \mathrm{AUD}$ and $1,000 \mathrm{tCO}{ }_{2} \mathrm{eq} /$ million AUD revenue. For the most emissions-intensive industries, an indicative carbon price of around $\mathrm{AU} \$ 20 / \mathrm{tCO}_{2} \mathrm{eq}$ was estimated to increase costs by around 10-15 per cent, compared to around 3-8 per cent for the next group of industries. Based on both domestic modelling and international studies, the government concluded that even the highly intensive EITE producers could bear some level of emission costs and did not need 100 per cent free allocation. The government had set an overall target for EITE industrial free allocation of about 20 per cent of the cap on units (leaving capacity for future agricultural free allocation) ${ }^{26}$ and expressed a preference for broader distribution of

\footnotetext{
${ }^{26}$ The Australian government's target for industrial free allocation at the start of the system was based on "an assessment of the materiality of the carbon cost on EITE industries, consideration of the share of the economy that EITE industries
} 
free allocation. With joint consideration of these factors, the government settled on emissions intensity thresholds and levels of assistance as a package: 90 per cent assistance for producers with emissions intensities above $2,000 \mathrm{tCO}_{2} \mathrm{eq} /$ million AUD revenue, and 60 per cent for intensities of $1,500-2,000 \mathrm{tCO}_{2} \mathrm{eq} /$ million AUD revenue. After further consultation and pushback from industry, the government lowered the bottom emissions intensity threshold to 1,000 $\mathrm{tCO}_{2} \mathrm{eq} /$ million AUD revenue (Australian Department of Climate Change 2008a). The government subsequently proposed incorporating a "global recession buffer", increasing the levels of assistance to 94.5 per cent and 66 per cent for the two categories (Ministry for the Environment 2009b). Although the CPRS did not enter into law, this free allocation package was largely carried into the CPM (Australian Department of Climate Change and Energy Efficiency 2011).

In the CPM legislation, the Productivity Commission was required to conduct an inquiry in each review period ${ }^{27}$ in order to assess and improve assistance to EITE producers under the JCP. It was to have regard to the following matters, listed in section 156(2) of the Clean Energy Act 2011:

- Whether JCP assistance was still warranted on the basis of whether foreign competing markets or major emitting countries had implemented emissions reduction measures with impacts comparable to those of Australia

- $\quad$ Progress made by free allocation recipients to improve emissions intensity

- Whether eligibility should be extended to additional EITE activities

- The relative impact of the emissions reduction policies of foreign competitors, and whether it would be feasible and appropriate to change the methodology for free allocation accordingly

- Whether the legislation was conferring windfall gains to EITE producers

- $\quad$ The effect of not imposing an emissions cap on EITE producers

- The growth of EITE production and its implications for free allocation within the cap

- The appropriateness of supplementary free allocation for liquified natural gas

- The impact of the Act and associated provisions on the competitiveness of EITE producers

- Whether the assistance to a specific industry should be changed

- Whether the JCP was supporting Australia's medium- and long-term emission reduction goals and the government's objectives under the legislation

comprise, and preliminary judgments about the appropriate distribution of assistance between EITE industries and other sectors, particularly households" (Australian Department of Climate Change 2008b).

27 The review periods were every 12-18 months from July 2014 through December 2018, and every five years from January 2019. 
- $\quad$ Other matters specified by the Productivity Minister or Productivity Commission.

When considering the policies of foreign competitors and whether to change assistance to a specific industry, the Productivity Commission was tasked to consider:

whether less than $70 \%$ of the relevant competitors of each emissions-intensive tradeexposed industry are located in foreign countries where the impact on those competitors of emissions reduction measures (including the impact of associated assistance) is comparable to the impact on the industry of Australian emissions reduction measures (including the impact of associated assistance) (Clean Energy Act 2011, section 156[3]). ${ }^{28}$

When considering windfall gains and competitiveness impacts, the Productivity Commission was tasked to consider:

(a) an analysis of the carbon cost passed on (to and by emissions-intensive trade-exposed industries);

(b) the reduction in emissions of greenhouse gases resulting from emissions-intensive tradeexposed activities; and

(c) the effect of a declining rate of assistance under the Jobs and Competitiveness Program on emissions-intensive trade-exposed activities (Clean Energy Act 2011, section 156[5]).

This review process was never undertaken, as the CPM was abolished in July 2014 . The legislation highlights the complexity of the considerations that could potentially apply to conducting a more refined assessment of the carbon leakage and competitiveness impacts of emissions pricing.

\section{$5 \quad$ Options for improving industrial free allocation in the NZ ETS post-2021}

As detailed in Section 3.4, the Climate Change Response (Emissions Trading Reform) Amendment Act 2020 defines a default pathway through 2050 for phasing out industrial free allocation and defines a new process enabling the Minister for Climate Change to adjust the rate of phase-out in either direction for individual activities (or all activities) with advice from the Climate Change Commission. In legislation, the scope for that adjustment is limited to the level of assistance (i.e. assistance factor). The government also has the power to modify the EAF, which is defined in the Climate Change (Eligible Industrial Activities) Regulations 2010.

Having adjusted industrial free allocation in the 2020 amendments, the government is still considering further changes. This is in recognition of the fact that the ongoing use of outdated eligibility criteria and allocative baselines could result in windfall gains through overallocation.

\footnotetext{
${ }^{28}$ For comparison, when assessing trade exposure, the Australian government had set a threshold of 10 per cent for the trade share, defined as 100 times the ratio of (annual value of imports + exports) / (annual value of production) (Australian Government 2012).
} 
Officials have been directed to work on resource needs for reviewing eligibility and updating allocative baselines, options for adjusting the base period for allocative baselines in legislation, a potential role for the Climate Change Commission to advise on updating allocative baselines, and considering whether new industrial activities started after the introduction of emissions pricing should receive free allocation (which is currently the case). The Minister's stated objectives were to "ensure the allocations received by EITE firms are fair representations of their current emissions intensities, and that only those activities that are actually emissions intensive and trade exposed, using the existing eligibility tests, are able to receive industrial allocation" (Cabinet Environment, Energy and Climate Committee 2019). ${ }^{29}$

Setting aside the scope of the Minister's direction, the government's options for further reform can be categorised as follows:

1. Changing the eligibility criteria for industrial free allocation

2. Changing the methodology for calculating industrial free allocation

3. Introducing alternatives to industrial free allocation

4. Accepting and managing emissions leakage.

This section examines reform opportunities across these sets of options.

\subsection{Eligibility to receive free allocation}

In the three systems considered in this paper, eligibility to receive industrial free allocation is based on the degree of trade exposure (a proxy for a producer's ability to pass on prices) and the emissions intensity of production (a proxy for the materiality of emissions costs to profitability). In the New Zealand context, reforms could be applied to refine either or both of these tests or to expand the scope of considerations for assessing leakage risk.

\subsubsection{Refining the assessment of trade exposure}

\section{Assessing trade exposure for individual activities with materiality thresholds for trade}

intensity would better enable policy makers to account for variable degrees of import/export competition (trade intensity) across activities. In New Zealand, trade exposure is a binary judgement and no consideration is given to the degree of trade intensity and its implications for price pass-through. A more nuanced approach could account for actual trading dynamics across diverse activities and markets. Periodically reassessing trade exposure would enable policy

\footnotetext{
${ }^{29}$ As noted in the introduction, the government released a consultation document in July 2021 on reforming industrial allocation (Ministry for the Environment 2021b). This falls outside the scope of this paper.
} 
makers to account for changes in commodity production and trade patterns over time and their relevance for emissions leakage.

\subsubsection{Assessing eligibility using a New Zealand electricity emission factor}

As discussed in Section 3.2, the current eligibility test calculates the emissions of New Zealand producers relative to the emissions intensity thresholds using an Australian electricity allocative factor. As an obvious first step for reform, the government could apply a New Zealand-specific (and updated) EAF instead when assessing eligibility. The government could consider assessing eligibility using a fixed New Zealand EAF or periodically reassessing eligibility using updated New Zealand EAFs. Enabling periodic reassessment of emissions intensity with an updated EAF could be appropriate to avoid windfall gains to producers. The EAF is addressed in more detail in Section 5.2.3. Further analysis would be needed to determine whether changing to a significantly lower and more realistic EAF would have a material impact on eligibility for free allocation.

\subsubsection{Redefining emissions intensity thresholds}

Policy makers could redefine the emissions intensity thresholds used to determine which tradeexposed producers qualify as highly or moderately intensive. As discussed above, moderately intensive sectors have an emissions intensity of at least 800 and less than 1,600 $\mathrm{tCO}_{2} \mathrm{eq} / \mathrm{million}$ NZD revenue, and highly intensive sectors have an emissions intensity of at least 1,600 $\mathrm{tCO}_{2} \mathrm{eq} /$ million NZD revenue. Two levels of change are possible.

A deeper level of reform would involve recalculating (or adding) emissions intensity thresholds to better reflect actual leakage risk. The value in doing this depends on the purpose of these thresholds. If they are intended to merely rank trade-exposed producers according to the magnitude of the effect of emissions pricing, then the current approach may suffice. If they are meant to reflect the actual materiality of emissions costs to production decisions relevant to emissions leakage, then more refined assessment may be required across a range of projected emission prices and activities. A further option would be to update the thresholds periodically to reflect changing market conditions, provided this did not create perverse incentives for firms to avoid improving their emissions intensity in order to retain access to free allocation.

In that context, it is useful to revisit the rationale for the Australian government's methodology for emissions intensity assessment that was adopted by New Zealand (detailed in Section 4.3). A key insight from this history is that New Zealand adopted emissions intensity thresholds driven by both technical and political considerations specific to the Australian industrial and trade contexts using data that are now 20 years old. The motivation for this was alignment of free allocation regimes across New Zealand and Australia - a consideration whose 
relevance has changed. Further analysis could be conducted to determine whether those thresholds reflect the likelihood that future emission costs would influence EITE industries in New Zealand to reduce or stop production at projected emission price levels alongside other factors such as changes in exchange rates, global energy and commodity prices, technologies, and other domestic policies.

Sense Partners (2018) assessed the impacts of emission prices on the profits of tradeexposed producers in New Zealand and found that while average firms could absorb relatively high emission prices with reduced profitability, others (particularly primary metals) would be highly sensitive to price increases. One important caveat is that debt obligations were not considered. Results are presented in Figure 4. The authors tested the sensitivity of these findings to projected business-as-usual improvements to emissions intensity in 2030 and 2050 and concluded that such improvements would not make a material difference to the impact of emission costs except for those who were highly sensitive to electricity and transport costs. The authors observed that at the level of firm-specific analysis, emissions pricing was not the key determinant of commercial viability; factors such as exchange rates, international commodity prices, input costs, and market competition were more significant. 
Figure 4: Impacts of carbon prices on firm profits, current ETS scope

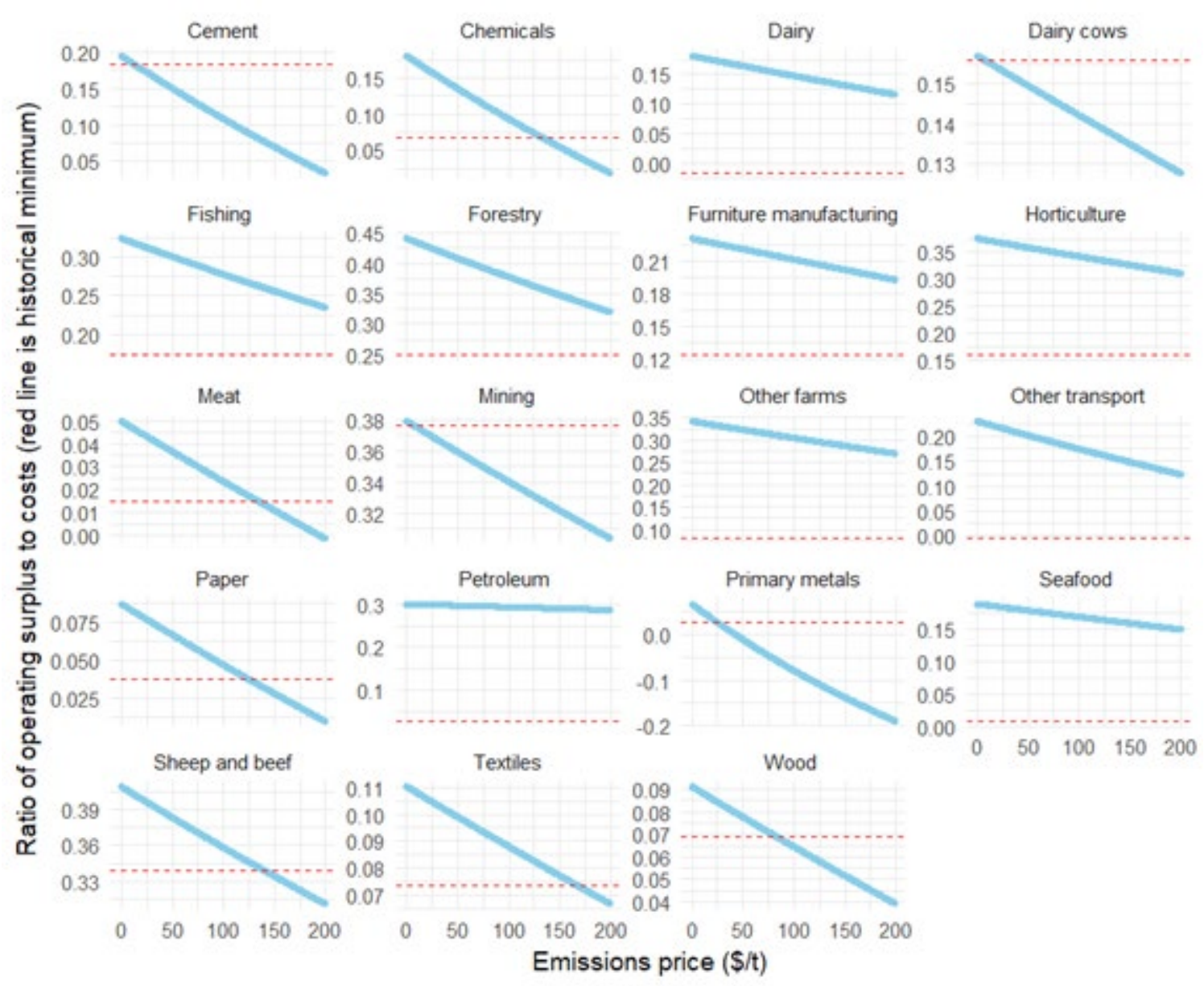

Source: Sense Partners (2018). Note: The "current ETS scope" reflected 2018 conditions and excluded biogenic emissions from agriculture. According to Sense Partners, "The blue line is the profit-to-cost ratio as carbon price varies. Carbon prices reflect NZU prices, rather than effective carbon rates. The red line is the minimum historical value." 30

\section{Conducting activity-specific assessment of the materiality of emissions costs to domestic}

production instead of applying generic thresholds could offer a more refined approach. This could also be a very complex and resource-intensive process involving confidential business information, and could make transparent and consistent assessment of eligibility very challenging. The increased administrative costs would need to be weighed against the potential benefits of higher auction revenue. A simplified approach could involve revising the current eligibility thresholds for groups of activities, either following the current division into highly intensive versus moderately intensive producers, or with the addition of further tiers of intensity, thereby enabling greater customisation across producer characteristics. In all cases, the government would likely need to apply counterfactual assumptions about the level of emission prices in the future and its materiality relevant to changes in other drivers of

\footnotetext{
${ }^{30}$ According to Sense Partners (2018), "This presentation is based on industry profitability according to national accounts data for 2016. This was a year of poor profitability for a few sectors, which is why the red line intersects the maximum value for profitability for that sector, as in the case of Dairy Cow farming."
} 
profitability. It could benefit from the past decade of observing how New Zealand producers have responded to relative changes in the prices of emissions, energy, and globally traded commodities.

\subsubsection{Expanding the criteria for assessing emissions leakage risk}

While trade exposure is a key risk factor for emissions leakage, additional factors influence the extent to which trade-exposed producers can pass on emission costs. The government could consider adding a broader range of factors for assessing emissions leakage risk beyond trade exposure to include consideration of constraints to price pass-through. Having reviewed a range of studies, Acworth et al. (2020) suggest that trade intensity by itself is not sufficient for predicting emissions leakage risk. They identify six additional criteria that could be used: the emissions intensity of competing producers, emissions constraints in competing jurisdictions, the availability and cost of mitigation technologies, market structure and the nature of competition, price and trade elasticities, and profit margins. While metrics are identified for applying each of these criteria, each poses significant challenges to use in practice given data limitations and the complexity and variability of assessment. The relevance of different criteria could vary by activity and jurisdiction, leading to cherry picking. One solution is targeting detailed assessment to specific activities or groups of activities. Examples could include the relatively small number of large free allocation recipients or those with more uncertain or material leakage risk.

In New Zealand, some producers have suggested adopting the "70 per cent test" that was intended to help inform future assessments of free allocation needs by Australia's Productivity Commission under the Australian CPM (Ministry for the Environment 2019a,b). As discussed in Section 4.3, when considering whether to change assistance to a specific industry, the Australian Productivity Commission was tasked in legislation to consider whether less than 70 per cent of the relevant competitors were located in foreign countries with emissions reduction measures comparable to those of Australia. This was only one in a very long and complex list of considerations specified for deciding on changes to industrial free allocation. The legislation did not present a rationale for the 70 per cent threshold, and nor did it define how comparability of policy ambition was to be measured. Based on the insights from Acworth et al. (2020), cherry picking this single consideration would not appear to produce a comprehensive assessment of emissions leakage risk.

Given the complexity of the issues discussed above, one option would be conducting integrated assessment of quantitative and qualitative factors, potentially spanning trade exposure, emissions intensity, and other considerations. For example, as shown in Figure 5, the 
CA CAT developed a detailed typology of carbon leakage risk, with three levels of leakage risk (high, medium, and low) derived from 12 combinations for high, medium, and low levels of emissions intensity and trade exposure (California Air Resources Board 2010). Although California's legislation applies an assistance factor of 100 per cent across eligible industrial recipients, this typology for differentiation of leakage risk was recommended by officials (California Air Resources Board 2018) and could be worth further consideration in the New Zealand context. For borderline sectors, the EU ETS moved beyond a pure quantitative assessment for carbon leakage risk. In a second-level assessment, it also evaluates the capacity of the installation to reduce emissions or electricity consumption, non-quantitative market characteristics (for example, market concentration, competition, homogeneity of production, and bargaining power), and trends in long-run investment.

Assessing emissions leakage is an international challenge and other jurisdictions may be better resourced to manage it. New Zealand could consider applying international leakage assessments led by other jurisdictions for major globally traded commodities. It could then limit its own detailed assessment to commodities whose leakage potential is uniquely influenced by New Zealand's national circumstances.

\subsection{Methodology for calculating industrial free allocation}

In New Zealand, the formula for calculating industrial free allocation is defined in legislation, so changes would require amendments. This section evaluates a range of possible changes to the following variables in the standard free allocation equation used internationally: the basis for provision (output versus grandparenting); the benchmark factor (allocative baseline), including the EAF; the assistance factor; and a cap adjustment factor.

\subsubsection{Basis for provision of free allocation}

The government could consider changing from output-based free allocation to grandparenting or to an output basis with infrequent updating of output. In New Zealand's context, where emissions pricing has been operational for over a decade, switching from output-based free allocation with frequent updating to grandparenting or infrequent updating would be disruptive. It is not obvious what historical period would be appropriate for grandparenting units or fixing output. The potential gains from better incentivising mitigation at the margin could be negated by increased leakage risk and slower adaptability to changing market conditions, and the entry or exit of eligible producers. The rationale for industrial free allocation remains focused on leakage prevention, not compensation for stranded assets from policy changes adopted over a 
decade ago. If the government retains industrial free allocation, the case for staying with an output-based approach with frequent updating appears reasonably strong.

\subsubsection{Applying a more ambitious benchmark (allocative baseline) methodology}

Benchmark factors (emissions per unit of output) can be constructed from past or projected emissions using different standards for ambition. Across jurisdictions with emissions trading, free allocation benchmarks have resulted from deep technical assessments, political decisionmaking, and negotiation processes (Secretaria de Medio Ambiente y Recursos Naturales and Deutsche Gesellschaft für Internationale Zusammenarbeit 2018).

The government could consider replacing the current sector-average approach with a more ambitious benchmark methodology. For example, New Zealand could explore applying benchmarks reflecting international "best practice". The logic behind this would be holding New Zealand producers to a high international standard applicable across globally traded commodities. The reality is that such standards are the exception rather than the rule across different types of commodities at present. Under the NGA policy in place over 2002-2005, the New Zealand Government found it very challenging to define "world's best practice" benchmarks suited to New Zealand's national circumstances. This is an area where further international collaboration could be helpful for both sharing information on the performance of existing and emerging technologies and developing a more coordinated approach to managing emissions leakage risk across key commodities.

Attempting to compare New Zealand's current allocative baselines against those in specific jurisdictions highlights differences across jurisdictions in benchmarking methodologies, technologies, energy resources, and market conditions. ${ }^{31}$ As discussed in Section 3.2, New Zealand uses the average of the direct and indirect sector emissions over a three-year historical period (2006/2007 to 2008/2009 for most producers). The EU ETS sets its benchmarks using the top 10 per cent of installations and excludes indirect emissions from electricity generation (which receive separate compensation). The CA CAT system applies a hybrid model by first calculating 90 per cent of the sector average and then applying the "best-in-class" value if the first method gives a higher value than the most efficient installation. Like New Zealand, California integrates indirect emissions from electricity into its benchmarks. The California EAF is

\footnotetext{
${ }^{31}$ Comparing New Zealand's performance to international standards is complicated for many commodities because many of New Zealand's producers use technologies and inputs that have been adapted to national circumstances. Such comparison proved very complex when New Zealand attempted to define "world's best practice" benchmarks for EITE producers under Negotiated Greenhouse Agreements (NGAs). NGAs were part of the government's 2002 climate change policy package. They enabled exemptions from the proposed carbon tax in return for a commitment by the producer to achieve a pathway toward world's best practice in emissions intensity. Only two NGAs were actually agreed.
} 
$0.431 \mathrm{tCO}_{2} \mathrm{eq} / \mathrm{MWh}$ compared to $0.537 \mathrm{tCO}_{2} \mathrm{eq} / \mathrm{MWh}$ in New Zealand. In 2019, California's generation mix contained 32 per cent renewable energy across in-state and imported sources (California Energy Commission 2021), compared to 82 per cent in New Zealand (Ministry of Business, Innovation and Employment 2020). New Zealand's relatively higher EAF, despite substantially greater renewable generation, reflects the structure of its electricity pricing regime, as discussed in Section 3.2.

The sample listing of benchmarks in Table 6 highlights differences across the ETSs considered in this paper. Where jurisdictions apply different definitions to industrial outputs, use different calculation methodologies, and include different scopes of emissions (direct and indirect), it is currently impractical to directly compare benchmark quality and ambition. Furthermore, the relative generosity of free allocation in different jurisdictions cannot be compared based on benchmarks alone, as outcomes are also driven by variable assistance levels and cap adjustment factors.

If it proved impractical or ineffective to compare New Zealand production to international benchmarks, then an alternative could be applying benchmarks reflecting a top percentile of domestic sector performance, as has been done in other jurisdictions. However, New Zealand's small size is a complication here. Of 23 sectors that are eligible for free allocation, 15 have only one producer, so in those cases the "sector average" is producer specific (Environmental Protection Authority 2019a). Given the complex drivers of leakage, developing more precise benchmarks would not necessarily produce more refined outcomes for addressing leakage risks in return for the effort required. It is useful to consider that reducing the level of assistance can produce comparable outcomes to increasing benchmark stringency.

Another way of boosting ambition would be through applying benchmarks with set annual improvement factors reflecting sector efficiency improvements under business-asusual. A predictable annual adjustment for projected changes in energy efficiency or emissions intensity (direct emissions only) could be made to each allocative baseline to help reduce the risk of overallocation. ${ }^{32}$ As with the previous option, a similar result could also be achieved by reducing the level of assistance.

\footnotetext{
${ }^{32}$ As noted in Section 4.1, the EU is doing this from 2021.
} 
Table 6: Sample benchmark factors in the NZ ETS, EU ETS and CA CAT

\begin{tabular}{|c|c|c|c|c|c|c|}
\hline Activity & \multicolumn{2}{|c|}{ NZ ETS } & \multicolumn{2}{|c|}{ EU ETS ${ }^{33}$} & \multicolumn{2}{|l|}{ CA CAT } \\
\hline \multirow{2}{*}{$\begin{array}{l}\text { Aluminium } \\
\text { smelting }\end{array}$} & $\begin{array}{l}\text { Primary } \\
\text { aluminium }\end{array}$ & $4.94^{34}$ & $\begin{array}{l}\text { Primary } \\
\text { aluminium } \\
\text { without } \\
\text { casting }\end{array}$ & 1.6 & & \\
\hline & & & $\begin{array}{l}\text { Secondary } \\
\text { aluminium }\end{array}$ & 0.22 & $\begin{array}{l}\text { Secondary } \\
\text { smelting and } \\
\text { alloying of } \\
\text { aluminium }\end{array}$ & 0.409 \\
\hline \multirow{4}{*}{$\begin{array}{l}\text { Iron and steel } \\
\text { manufacturing } \\
\text { from iron sand }\end{array}$} & Molten iron & 3.2613 & Hot metal & 1.2861 & & \\
\hline & $\begin{array}{l}\text { Flat products } \\
\text { of hot-rolled } \\
\text { carbon steel }\end{array}$ & 0.163 & & & \multirow{2}{*}{$\begin{array}{l}\text { Hot-rolled } \\
\text { steel sheet }\end{array}$} & \multirow{2}{*}{0.093} \\
\hline & $\begin{array}{l}\text { Long products } \\
\text { of hot-rolled } \\
\text { carbon steel }\end{array}$ & 0.147 & & & & \\
\hline & & & $\begin{array}{l}\text { EAF crude } \\
\text { steel }\end{array}$ & 0.058 & $\begin{array}{l}\text { Steel produced } \\
\text { using EAF }\end{array}$ & 0.187 \\
\hline \multirow{2}{*}{ Burnt lime } & Burnt lime & 1.4115 & Lime & 0.985 & & \\
\hline & & & Dolime & 1.113 & $\begin{array}{l}\text { Dolime } \\
\text { produced }\end{array}$ & 1.543 \\
\hline \multirow[t]{2}{*}{$\begin{array}{l}\text { Cementitious } \\
\text { products }\end{array}$} & $\begin{array}{l}\text { Dry weight } \\
\text { Portland } \\
\text { cement } \\
\text { clinker }\end{array}$ & 0.9615 & $\begin{array}{l}\text { Grey cement } \\
\text { clinker }\end{array}$ & 0.78 & $\begin{array}{l}\text { Adjusted } \\
\text { clinker and } \\
\text { mineral } \\
\text { additives } \\
\text { produced }\end{array}$ & 0.818 \\
\hline & $\begin{array}{l}\text { Dry weight } \\
\text { cement }\end{array}$ & 0.0234 & & & & \\
\hline
\end{tabular}

Source: Adapted from Ecofys et al. (2009a,b,c,d); California Air Resources Board (2019); New Zealand Government (2020)

\subsubsection{Updating the electricity allocation factor}

The most obvious option for reform would be enabling more frequent updates of the EAF. The current EAF that is incorporated into activity-specific allocative baselines (but not eligibility assessment) is a modelled value designed to apply from 2013 to 2020 . As summarised by the Ministry for the Environment (2019d), "The core technique was a combination of a long-run

\footnotetext{
${ }^{33}$ Note that the benchmarks for the EU ETS exclude indirect emissions from electricity, which receive separate compensation.

${ }^{34}$ Average 2010-2020
} 
marginal cost model to determine new generation build mix, and a short-run marginal cost model to simulate the operation of the electricity system."

The government took a first step towards updating the EAF in December 2019 when it began consultation on options. It commissioned two independent studies that evaluated the EAF from different perspectives. The first compared the actual EAF in the wholesale market over 2016 and 2017 with the modelled EAF. The second compared key input values for modelling against actual input values. The outcomes from both studies suggest that the modelled EAF may have overcompensated participants for the effect of the NZ ETS on electricity prices given how actual generation had evolved since the modelling was done. However, this effect could have varied over the period (Ministry for the Environment 2019d).

During initial consultation, the government requested input on proposed modelling parameters and values and on when the EAF should be reviewed, but not on options for more fundamental changes to the process for assessing the impact of the NZ ETS on electricity prices. Decisions on changes were deferred due to the COVID-19 pandemic (Ministry for the Environment 2020a).

Over April to May 2021, the government consulted further on specific options for revising the EAF (Ministry for the Environment 2021a). Further modelling conducted since the previous consultation affirmed that the EAF over 2013 to 2020 may have overcompensated participants. The government proposed the following options for consideration:

- $\quad$ Updating the fixed EAF to apply for a defined period (e.g. through 2026) using scenario modelling

- $\quad$ Conducting a rolling update of the EAF using the previous year's data

- $\quad$ Conducing a rolling update of the EAF using average data over a longer historical period (e.g. 3-4 years).

A key consideration is the potential for both the industrial and electricity sectors to undergo substantial structural changes due to both market and regulatory drivers. The relationship between emissions pricing and electricity pricing can be expected to change over time. A methodology that locks in a modelled EAF for long periods of time may prove untenable and pose both fiscal and target risks.

\subsubsection{Updating the base years for allocative baselines}

Officials have already been directed by Cabinet to consider options for updating the base years for allocative baselines. The allocative baseline calculations are now more than a decade out of date. One consideration is that the production landscape has changed significantly in some 
sectors. For example, in the cementitious products sector, the allocative baseline was set as the industry average across two producers: Fletcher Concrete and Infrastructure Limited, which uses a "dry process"; and Holcim (New Zealand) Limited, which used a less efficient "wet process". Holcim Cement exited the New Zealand market in 2016, but Fletcher Building continues to benefit from the less stringent allocative baseline. A further consideration is that production methods have improved over time. For example, New Zealand's industrial producers have historically demonstrated energy efficiency improvements of 1 per cent per year. This was expected to continue from 2017 to 2022 in forecasts applied in the New Zealand Energy Efficiency and Conservation Strategy assuming existing measures (Ministry of Business, Innovation and Employment and Energy Efficiency and Conservation Authority 2017). Over the past decade, allocative baselines with respect to energy consumption per unit of output have stayed the same while energy efficiency in the industrial sector can be assumed to have improved 10 per cent under business-as-usual. Similar trends in improvement may not apply to industrial-process emissions that are driven by chemistry.

The government could consider making a one-off change to the base years for allocative baselines. There may be both pros and cons to using a more recent set of base years. Recalculation could improve alignment of free allocation levels with actual emissions, generating both fiscal and target benefits for New Zealand while reducing windfall gains to recipients. One downside would be a loss of policy continuity, which could devalue previous investment decisions made by free allocation recipients. This could reduce market confidence in government rule-making.

An alternative would be requiring periodic base-year updates on a predictable basis. An important consideration is how often allocative baselines would be recalculated. Frequent adjustment could perversely discourage firms from improving their emissions performance, since that would reduce the amount of free allocation they could expect to receive in the future as well as the return on their investment in reducing emissions.

In both cases, a further downside to recalculation would be the technical and political complexity of choosing the new base years. A given set of base years might advantage or disadvantage different sectors and have significant and competing implications for corporate bottom lines, as well as for the Crown accounts and New Zealand's domestic and international emission reduction targets. 


\subsubsection{Modifying the base levels of assistance}

As discussed in Section 3.4, the NZ ETS applies two base levels of assistance (90 per cent and 60 per cent of allocative baselines) and uses assistance levels as the lever for managing phase-out. Direct comparison of assistance factors across ETSs is challenging; any comparison of ambition should jointly consider assistance factors, benchmark factors, and cap adjustment factors. For EITE producers, the EU ETS provides an assistance level of 100 per cent, although this is applied to a relatively more ambitious allocative baseline (the top 10 per cent of sector production in the EU, compared to the sector average in New Zealand). In the EU, the cost of indirect emissions from electricity is covered through alternative compensation. California provides assistance at 100 per cent of the allocative baseline for direct and indirect emissions, set at 90 per cent of the sector average. Both the EU and CA systems apply cap adjustment factors to free allocation (as discussed in Section 5.2.6).

A first alternative to the current regime would be changing the base levels of assistance to better align with leakage and overallocation risk. The government could reduce the current base levels if further analysis suggested that leakage risk was relatively low and/or overallocation was a significant concern. A second alternative would be introducing further levels of assistance to better manage variability among producers. This could enable the government to target free allocation more precisely where it is needed and avoid overallocation. It could also smooth the effects of being slightly above or below a threshold for assistance.

\subsubsection{Applying more ambitious default phase-out rates}

The government could consider increasing phase-out rates to better align with projected target pathways through 2050. Allowing up to 30 per cent free allocation to highly intensive producers in 2050 does not appear consistent with the target of net-zero emissions of long-lived GHGs. The government had consulted on options for annual phase-out ranging up to 3 per cent per year from as early as 2021, but did not consider higher rates. While deliberating on legislative amendments in 2019, the government indicated it would not consider higher rates for phase-out because they would be outside the range of consultation and "such rates are not likely to be necessary to meet emissions budgets" (Ministry for the Environment 2019a). The logic behind the latter assessment is not clear, given that emissions budgets had not yet been set at the time, New Zealand faces a challenging transition to reach net-zero emissions of long-lived GHGs by 2050 on a pathway compatible with the global temperature goal of $1.5^{\circ} \mathrm{C}$, and this decision has significant fiscal implications for the government and equity implications for other sectors. 
The government could also consider increasing phase-out rates to compensate for other shortcomings in the free allocation methodology. As an alternative or complement to making complex changes to the methodologies for determining eligibility and setting allocative baselines, the government could choose to increase the phase-out rates for industrial free allocation. This approach could help manage target and fiscal risk, and avoid overallocation and windfall gains to recipients. This approach may be feasible without legislative amendment.

\subsubsection{Introducing a cap adjustment factor to constrain free allocation}

A key difference between the NZ ETS and systems in other jurisdictions to date has been the absence of an absolute cap on domestic emissions. Under the 2020 amendments, a new overall limit on units was introduced in 2021. This restrains auctioning and future use of overseas units but does not bind output-based free allocation. The absence of an overall limit on output-based free allocation potentially makes it more difficult to align free allocation with emissions budgets and the 2050 target. If free allocation pushes domestic emissions above an emissions budget, the government is required to compensate using offshore mitigation or additional emission reductions elsewhere. In contrast, the ETSs in the EU and California both apply cap adjustment factors to align free allocation with intended cap trajectories over time. These essentially scale down free allocation as needed to fit within specified emission limits.

The government could introduce some form of cap adjustment factor to constrain free allocation and manage the risk that unexpectedly high levels of free allocation could push domestic emissions beyond the emissions budget. This would be an alternative to a set phaseout rate for free allocation operating independently of the cap. Such an option may become more important strategically as New Zealand approaches net-zero emissions of long-lived GHGs by 2050 and purchasing of offshore mitigation becomes more difficult and expensive. In addition to potentially being incompatible with the 2050 target and limits to the future availability of offshore mitigation, this legislated commitment to enabling free allocation through 2050 may raise significant issues over time regarding fair access to emission units across sectors and proper functioning of the ETS, including the operation of price management measures, with very low levels of auctioning.

\subsection{Alternatives to industrial free allocation}

\subsubsection{Providing up-front transitional assistance}

New Zealand could consider other forms of up-front transitional assistance as complements to, or substitutes for, free allocation to boost efficiency improvements and innovation and 
encourage substitution of low-emission alternative products. Assistance could take the form of grants, subsidies, tax incentives, financing, and/or technical assistance.

For some producers (for example, those with high trade exposure, high emissions intensity, and limited mitigation options), some form of output-based free allocation, combined with innovation policy, may remain the most effective, practical, and politically acceptable solution to mitigate the risk of emissions leakage in the near term. However, for other producers, the government could consider the relative costs and benefits of providing up-front assistance in place of free allocation. Producers with lower levels of free allocation and/or available mitigation options potentially could benefit from replacing annual amounts of free allocation with up-front assistance that enables step-change investments in reducing emissions while avoiding ETS transaction costs. For context, in 2018, 21 highly intensive producers received 94 per cent of freely allocated NZUs, with the remaining 6 per cent distributed across 63 moderately intensive producers. In that year, 48 producers received less than 5,000 units per year and 24 received less than 1,000 units per year (Environmental Protection Authority 2019a). The potential benefits of this approach may not be restricted to producers with low emission profiles. The government could consider combining up-front assistance with an accelerated phase-out of free allocation to smooth the transition.

To be effective, such transitional assistance should be performance based (for example, structured as a grant for clean investment), rather than provided as compensation. ${ }^{35}$ The government would need to consider interactions between ongoing free allocation, leakagebased transitional assistance, and broader transitional assistance motivated by different goals. Policy continuity is another important consideration. The experience of the Australian CPM offers a cautionary tale. At the time of its implementation, the government provided lump-sum financial assistance to coal-fired generators to help with the transition to emissions pricing, as they were not trade exposed and therefore were ineligible for free allocation. The government subsequently abandoned the CPM but the generators kept the payments. Sustained political commitment to policy design and producer commitment to domestic output would be crucial to the success of alternative approaches to transitional assistance.

\subsubsection{Introducing border carbon adjustments}

The government could consider applying BCAs. Conceptually, an emission price would be added to at the point of import into New Zealand for goods from jurisdictions without comparably

\footnotetext{
35 This approach has been proposed in the European Commission's "Fit for 55" policy package. As noted in Section 4.1, free allocation in the EU ETS will be made conditional on implementing cost-efficient measures recommended in energy audits (European Commission 2021c).
} 
stringent climate change policies, and New Zealand producers would get a rebate for the emission price paid on the goods manufactured domestically for export. A benefit of this approach is that domestic consumers would face an emission price on both domestic and imported products, and domestic producers could pass on the cost of emissions domestically and reap further rewards from innovation. In this way, BCAs would enable a full emission price signal to be passed to consumers to change behaviour, whereas that signal is blunted by outputbased free allocation and - in the case of some imports - the absence of any emissions pricing.

BCAs have been considered periodically by other jurisdictions seeking to "level the playing field" between domestic producers and external competitors and they have featured in the EU's proposal for a Green Deal (European Commission 2020). In July 2021, the European Commission issued a proposal for a CBAM (European Commission 2021a). This would cover direct emissions (excluding electricity) from the following sectors: iron and steel, cement, fertiliser, aluminium, and electricity generation. Reporting would start in 2023 and obligations in 2026 . EU importers would need to purchase carbon certificates equivalent to the emission price that would apply as if the goods were produced in the EU. They could deduct the cost of any emission prices paid in a third country. Free allocation for CBAM sectors would be phased out from 2026, and the level of the CBAM would be adjusted to ensure a level playing field during the transition to zero free allocation by 2035. No emission price rebate would be provided for EU producers exporting to other jurisdictions. Exclusions would apply to non-EU jurisdictions participating in the EU ETS or linked to the EU ETS.

While the BCA concept has attracted clear political interest in some jurisdictions, it could be extremely complex to implement technically and politically and its compatibility with rules under the World Trade Organization could be subject to challenge (Acworth et al. 2020). Given the current barriers to this option, New Zealand may not wish to venture there unilaterally but instead could investigate options in collaboration with other jurisdictions. If it chose to proceed with a BCA regime, the government could consider aligning BCAs with international best practice or limiting BCAs to key commodities where implementation would be relatively straightforward. Over time, BCAs may become more politically acceptable and technically achievable for specific types of commodities - or become increasingly unnecessary if global mitigation effort increases.

\subsubsection{Introducing domestic consumption charges}

The government could consider adding consumption charges to domestic and imported goods. Domestic consumption charges can operate as an alternative to an ETS. Essentially, this is the 
approach used for synthetic GHGs in imported goods that are excluded from the NZ ETS and subject to a synthetic greenhouse gas levy instead. When operating alongside an ETS with output-based free allocation, consumption charges on both domestic and imported goods could help to strengthen emission price signals to consumers. Exclusions or rebates could apply to exports of domestic products. If consumption charges were perceived to operate more like a domestic value-added tax than a BCA, it is possible they would face less opposition under World Trade Organization rules. However, when combined with an ETS, they would not level emissions pricing across domestic and offshore producers and would not fully address leakage risk (Acworth et al. 2020).

\subsection{Accepting and managing emissions leakage}

Instead of having taxpayers fund free allocation to prevent emissions leakage, the government could opt to accept emissions leakage and manage the impacts. Domestically, the government could do this by supporting local workers and communities with transitioning to alternative employment. Internationally, the government could do so by increasing New Zealand's contribution to global mitigation by taking on a more ambitious international target or otherwise supporting additional mitigation in other countries.

It is important to evaluate whether the public and private welfare benefits of ensuring zero emissions leakage are worth the public cost. The closure of some industrial production in New Zealand and the redeployment of its labour and capital may be a necessary and ultimately beneficial part of the country's low-emission transition. The risk of leakage can be expected to decrease with the implementation of the Paris Agreement and increasing pressure for producers and investors to disclose and manage climate-related risk. It is possible that emissions leakage from New Zealand could have a minimal or even positive impact on global emissions if the recipient jurisdictions compensate for any emission increases under binding targets or are relatively more efficient producers.

\subsection{Summary of future options for industrial free allocation}

Table 7 provides a summary of the options identified in this paper for further reforms to industrial free allocation in the NZ ETS. Further analysis of these options is beyond the scope of this paper, and the inclusion of options in this table does not constitute an endorsement. The effectiveness of these options should be carefully evaluated with regard to criteria such as the practicality and transparency of implementation, the effectiveness at mitigating the risk of emissions leakage, consistency with emission reduction targets, maintaining incentives to reduce 
emissions, minimising net fiscal impacts, and avoiding perverse outcomes such as windfall gains to recipients. 
Table 7: Summary of reform options for industrial free allocation in the NZ ETS

\begin{tabular}{|c|c|c|c|}
\hline $\begin{array}{l}\text { Free allocation } \\
\text { parameter }\end{array}$ & Status quo & High-level options & Variations \\
\hline $\begin{array}{l}\text { Eligibility: trade } \\
\text { exposure test }\end{array}$ & $\begin{array}{l}\text { An activity is trade exposed unless there is } \\
\text { no international trade of the output of the } \\
\text { activity across oceans or it is not } \\
\text { economically viable to import or export the } \\
\text { output of the activity. Electricity generation } \\
\text { is not eligible }\end{array}$ & Changing the assessment of trade exposure & $\begin{array}{l}\text { - Assessing trade exposure for individual } \\
\text { activities using materiality thresholds for } \\
\text { leakage risk } \\
\text { - Periodically reassessing trade exposure }\end{array}$ \\
\hline \multirow[t]{2}{*}{$\begin{array}{l}\text { Eligibility: } \\
\text { emissions } \\
\text { intensity test }\end{array}$} & \multirow{2}{*}{$\begin{array}{l}\text { A one-off assessment of emissions intensity } \\
\text { uses two eligibility thresholds: } \\
\text { - Moderately intensive: at least } 800 \text { and less } \\
\text { than } 1,600 \mathrm{tCO}_{2} \mathrm{eq} / \text { million NZD revenue } \\
\text { - Highly intensive: at least } 1,600 \\
\text { tCO }{ }_{2} \mathrm{eq} / \text { million NZD revenue } \\
\text { - In both cases, emissions intensity is } \\
\text { calculated using an Australian electricity } \\
\text { emission factor }\end{array}$} & $\begin{array}{l}\text { Keeping the existing emissions intensity } \\
\text { thresholds but using a New Zealand } \\
\text { electricity emission factor to calculate } \\
\text { emissions intensity }\end{array}$ & $\begin{array}{l}\text { - Assessing eligibility using a fixed New } \\
\text { Zealand electricity emission factor } \\
\text { - Periodically reassessing eligibility using } \\
\text { updated New Zealand electricity emission } \\
\text { factors }\end{array}$ \\
\hline & & Changing the emissions intensity thresholds & $\begin{array}{l}\text { - Recalculating (or adding) emissions } \\
\text { intensity thresholds to better reflect } \\
\text { leakage risk } \\
\text { - Periodically reassessing emissions intensity } \\
\text { thresholds } \\
\text { - Assessing the materiality of emissions } \\
\text { costs to domestic production for individual } \\
\text { activities or groups of activities }\end{array}$ \\
\hline
\end{tabular}




\begin{tabular}{|c|c|c|c|}
\hline $\begin{array}{l}\text { Free allocation } \\
\text { parameter }\end{array}$ & Status quo & High-level options & Variations \\
\hline $\begin{array}{l}\text { Eligibility: other } \\
\text { criteria }\end{array}$ & None & $\begin{array}{l}\text { Expanding the criteria for assessing } \\
\text { emissions leakage risk }\end{array}$ & $\begin{array}{l}\text { - Adding consideration of factors such as: } \\
\text { The emissions intensity of competing } \\
\text { producers } \\
\text { Emissions constraints in competing } \\
\text { jurisdictions } \\
\text { The availability and cost of mitigation } \\
\text { technologies } \\
\text { Market structure and the nature of } \\
\text { competition } \\
\text { Price and trade elasticities } \\
\text { - Profit margins } \\
\text { - Targeting detailed assessment to activities } \\
\text { or groups of activities } \\
\text { - Conducting integrated assessment of } \\
\text { quantitative/qualitative factors } \\
\text { - Applying international leakage } \\
\text { assessments led by other jurisdictions }\end{array}$ \\
\hline
\end{tabular}

\footnotetext{
$\overline{36}$ List adapted from Acworth et al. (2020).
} 


\begin{tabular}{|c|c|c|c|}
\hline $\begin{array}{l}\text { Free allocation } \\
\text { parameter }\end{array}$ & Status quo & High-level options & Variations \\
\hline $\begin{array}{l}\text { Methodology: } \\
\text { output basis }\end{array}$ & $\begin{array}{l}\text { Unlimited output-based free allocation is } \\
\text { provided with annual updating of output. } \\
\text { Provisional free allocation is provided at the } \\
\text { start of a compliance year based on the } \\
\text { previous year's output and is adjusted after } \\
\text { the end of the compliance year to reflect } \\
\text { actual output }\end{array}$ & $\begin{array}{l}\text { Changing the basis for providing free } \\
\text { allocation }\end{array}$ & $\begin{array}{l}\text { - Changing to grandparenting } \\
\text { - Changing to an output basis with } \\
\text { infrequent updating of output }\end{array}$ \\
\hline \multirow[t]{3}{*}{$\begin{array}{l}\text { Methodology: } \\
\text { benchmark } \\
\text { factors }\end{array}$} & \multirow[t]{3}{*}{$\begin{array}{l}\text { Allocative baselines apply sector-average } \\
\text { emissions per unit of output, defined over } \\
2006 / 2007 \text { to } 2008 / 2009 \text { for most } \\
\text { producers. Indirect emissions from } \\
\text { purchased electricity are calculated using a } \\
\text { modelled Electricity Allocation Factor (EAF) } \\
\text { which is fixed for periods of time (e.g. 2010- } \\
2012 \text { and 2013-2020) }\end{array}$} & $\begin{array}{l}\text { Applying a more ambitious benchmark } \\
\text { methodology }\end{array}$ & $\begin{array}{l}\text { - Applying benchmarks reflecting } \\
\text { international "best practice" } \\
\text { - Applying benchmarks reflecting a top } \\
\text { percentile of domestic sector performance } \\
\text { - Applying benchmarks with set annual } \\
\text { improvement factors }\end{array}$ \\
\hline & & Updating the EAF & $\begin{array}{l}\text { - Updating a fixed EAF to apply for a defined } \\
\text { period using scenario modelling } \\
\text { - Conducting rolling updates of the EAF } \\
\text { using the previous year's data } \\
\text { - Conducting rolling updates of the EAF } \\
\text { using an average of data over a longer } \\
\text { historical period (e.g. } 3-4 \text { years) }\end{array}$ \\
\hline & & $\begin{array}{l}\text { Updating the base years for allocative } \\
\text { baselines }\end{array}$ & $\begin{array}{l}\text { - Making a one-off change to the base years } \\
\text { for allocative baselines }\end{array}$ \\
\hline
\end{tabular}




\begin{tabular}{|c|c|c|c|}
\hline $\begin{array}{l}\text { Free allocation } \\
\text { parameter }\end{array}$ & Status quo & High-level options & Variations \\
\hline & & & $\begin{array}{l}\text { - Requiring periodic base-year updates on a } \\
\text { predictable basis }\end{array}$ \\
\hline \multirow[t]{2}{*}{$\begin{array}{l}\text { Methodology: } \\
\text { assistance factors }\end{array}$} & $\begin{array}{l}\text { Eligible producers can receive two base } \\
\text { levels of assistance: } \\
\text { - Highly intensive: } 90 \text { per cent } \\
\text { - Moderately intensive: } 60 \text { per cent } \\
\text { Default assistance levels are reduced by: } \\
\text { - } 0.01 \text { in each year over } 2021-2030\end{array}$ & Modifying the base levels of assistance & $\begin{array}{l}\text { - Changing the base levels of assistance to } \\
\text { better align with leakage and } \\
\text { overallocation risk } \\
\text { - Introducing further levels of assistance to } \\
\text { better manage variability among } \\
\text { producers }\end{array}$ \\
\hline & $\begin{array}{l}-0.02 \text { in each year over } 2031-2040 \\
-0.03 \text { in each year over } 2041-2050 \\
\text { The default rates can be changed for } \\
\text { individual activities in either direction with } \\
\text { advice from the Climate Change Commission }\end{array}$ & $\begin{array}{l}\text { Applying more ambitious default phase-out } \\
\text { rates }\end{array}$ & $\begin{array}{l}\text { - Increasing phase-out rates to better align } \\
\text { with projected target pathways } \\
\text { - Increasing phase-out rates to compensate } \\
\text { for other shortcomings in the free } \\
\text { allocation methodology }\end{array}$ \\
\hline $\begin{array}{l}\text { Methodology: } \\
\text { cap adjustment } \\
\text { factor }\end{array}$ & None & $\begin{array}{l}\text { Introducing a cap adjustment factor to } \\
\text { constrain free allocation }\end{array}$ & \\
\hline $\begin{array}{l}\text { Alternative } \\
\text { measures }\end{array}$ & None & $\begin{array}{l}\text { Providing up-front transitional assistance: } \\
\text { grants, subsidies, tax incentives, financing, } \\
\text { and/or technical assistance }\end{array}$ & $\begin{array}{l}\text { - Providing up-front assistance in place of } \\
\text { free allocation } \\
\text { - Combining up-front assistance with an } \\
\text { accelerated phase-out of free allocation to } \\
\text { smooth the transition }\end{array}$ \\
\hline
\end{tabular}




\begin{tabular}{|c|c|c|c|}
\hline $\begin{array}{l}\text { Free allocation } \\
\text { parameter }\end{array}$ & Status quo & High-level options & Variations \\
\hline & & Border carbon adjustments & $\begin{array}{l}\text { - Implementing BCAs in line with } \\
\text { international norms as they emerge } \\
\text { - Limiting BCAs to key commodities }\end{array}$ \\
\hline & & Consumption charges & \\
\hline \multirow{2}{*}{$\begin{array}{l}\text { Accepting and } \\
\text { managing } \\
\text { emissions } \\
\text { leakage }\end{array}$} & \multirow[t]{2}{*}{ None } & $\begin{array}{l}\text { Supporting local communities and workers } \\
\text { with transitioning to alternative employment }\end{array}$ & \\
\hline & & $\begin{array}{l}\text { Increasing New Zealand's contribution to } \\
\text { global mitigation }\end{array}$ & $\begin{array}{l}\text { - Increasing international target ambition } \\
\text { - Supporting other countries to mitigate }\end{array}$ \\
\hline
\end{tabular}




\section{$6 \quad$ Cross-cutting considerations}

This section highlights some additional cross-cutting considerations relevant to designing future policy on industrial free allocation.

\subsection{Considering sectoral equity}

In a future where New Zealand is moving aggressively towards net-zero emissions of long-lived GHGs and industrial free allocation is phased out slowly, industrial free allocation could occupy an increasingly dominant share of the annual unit supply relative to auctioning. Over time, this could raise both equity and market power challenges for other market participants and interfere with the operation of the NZ ETS's price management mechanisms. It could also exacerbate equity issues for taxpayers losing the benefits of auction revenue under high emission prices. Under allocation decisions from 2010 to 2019, the government freely allocated more than 47 million NZUs to eligible industrial recipients (Environmental Protection Authority 2021b). For the period from 2021 to 2026, the government has projected freely allocating about 46 million more NZUs - at considerably higher emission prices than have applied in the past. This is equivalent to about 43 per cent of the projected auction volume over that period ${ }^{37}$ (Ministry for the Environment $2021 \mathrm{a}, \mathrm{c})$. This would have a value of about NZ\$2.3 billion at a sample emission price of NZ\$50 per unit.

\subsection{Maintaining predictability of unit supply for efficient price setting}

From 2021, the NZ ETS sets individual limits for auctioning and overseas units within an overall limit on supply that also accounts for free allocation. The overall limit does not bind free allocation, but free allocation that pushes unit supply above the overall limit must be backed by further emission reductions generated domestically or offshore. The government is required to announce the settings for unit supply and price management for five years in advance, but those decisions are fixed only for year 1 ; the government retains the flexibility to later adjust those settings for years $2-5$ (subject to greater constraints for years 2 and 3 ). This creates considerable uncertainty for the market about whether and how the government might adjust the announced auction supply in response to unanticipated changes in free allocation. For example:

\footnotetext{
${ }^{37}$ The projections of auction volume and industrial free allocation are subject to change. The auction volume referred to excludes the cost containment reserve volume.
} 
- If a large recipient of free allocation exits the market or significantly reduces production, will the corresponding volume of NZUs be added to the future auction supply or cancelled?

- If a large recipient of free allocation enters the market or significantly increases production, will the future auction volume be reduced to compensate?

- If the EAF changes relative to the value assumed when deciding NZ ETS unit supply settings in regulations, will the auction volume be adjusted?

A lack of policy guidance about the grounds for adjusting previously announced auction volumes relative to changes in forecast free allocation could hinder effective operation of the market and efficient investment decisions.

\subsection{Enabling policy stability}

The significant downside of changing eligibility criteria and updating the methodologies for free allocation is the introduction of new policy risk around which producers would continue to receive free allocation and how much they could expect to receive. Because the benefits of changes would likely be distributed unevenly within industrial sectors and between industry and government, these decisions would be politically charged. Significant changes could have the potential to destabilise cross-party and stakeholder support for the emissions trading. This level of policy risk could pose a major deterrent to ongoing operation and investment by EITE producers in New Zealand.

To reduce this policy risk, the government could narrow the scope for future changes. However, given the decarbonisation challenges facing New Zealand, further changes to the free allocation regime appear inevitable. For any changes to be successful, they must have a sound technical basis, secure enduring cross-party support, enable sufficient predictability to unlock investment, and be broadly acceptable to both producers and consumers. So far, past attempts at policy reform for industrial free allocation have failed this test. Each round of free allocation policy intended to define the future playing field for New Zealand producers has been fundamentally amended with each major change of government.

\section{Conclusion}

While informed by technical, economic, and fiscal considerations, decisions concerning the provision of industrial free allocation are ultimately about political choices in managing the transition to a low-emissions economy. In New Zealand, the primary rationales for providing industrial free allocation have been to mitigate the risk of emissions leakage to other 
jurisdictions and to avoid economic regrets from losing domestic production that would be viable if other jurisdictions adopted more ambitious climate change policies. The NZ ETS currently provides uncapped output-based free allocation to EITE industrial producers at two levels of assistance, for highly intensive and moderately intensive activities. The Climate Change Response (Emissions Trading Reform) Amendment Act 2020 prescribes default phase-out rates for industrial free allocation over 2021-2050, with the option for those rates to be adjusted in either direction for individual activities with advice from the Climate Change Commission.

In the New Zealand context, past research highlights differences in trade intensity, and the potential for emissions costs to be passed on or absorbed, across industrial activities currently eligible for free allocation. In the context where climate change regulation, mitigation opportunities, and consumer preferences will evolve at different speeds in New Zealand and other jurisdictions under the Paris Agreement, more refined and more frequent assessment of emissions leakage risk could be used to adjust eligibility thresholds and direct free allocation only where it is needed to mitigate leakage risk. In addition, updating allocative baselines to reflect changes in industry practice, introducing more targeted levels of assistance commensurate with leakage risk, and/or increasing the default phase-out rate for the levels of assistance could reduce the target, fiscal, and equity risks from overallocation.

Barring greater international harmonisation of climate change or industrial policies, industrial producers currently rated to have high trade exposure, high emissions intensity, and limited mitigation options could be expected to need some level of free allocation in the near term, combined with innovation policy, to prevent emissions leakage. For those producers with lower levels of free allocation and/or better access to mitigation options, the government could consider replacing free allocation with alternative forms of up-front transitional assistance that enable investment in efficiency improvements, process innovation, and alternative low-emission products to permanently avoid emissions and reduce costs, target risks, and administrative burdens for both recipients and regulators.

If other jurisdictions show support for credibly designed border carbon adjustments or consumption charges to level the playing field for trade-exposed producers, New Zealand could consider joining suit. Such mechanisms may be more practical to implement for specific commodities that are relatively homogeneous and highly trade exposed.

Further research will be needed to explore these options. More fundamentally, this is an important time to review the policy case for industrial free allocation. Past government policy was designed conservatively to prevent emissions leakage at considerable public expense. In fact, it appears likely that some producers have been overcompensated due to the use of 
outdated allocative baselines and EAFs and high levels of assistance. In today's context, climatedamaging emissions leakage is not a given just because production is trade exposed. The risk of emissions leakage for New Zealand's EITE producers can be expected to decline further with the implementation of the Paris Agreement and increased pressure for producers and investors to disclose and manage climate-related risk. While adopting more sophisticated methods to tailor free allocation to actual leakage risk could offer a potential solution, it would also increase policy complexity, transparency, and transaction costs, while being politically fraught.

The government should consider whether the public and private benefits of maintaining and improving industrial free allocation are worth the cost and complexity in the evolving international and domestic contexts. Further work is needed to assess whether replacing industrial free allocation with alternative measures, or accepting and managing emissions leakage, could prove a better use of public resources than paying EITE producers for emissions costs over decades to come. Ultimately, any future provision of industrial free allocation should be used to assist - and not block - the transition to an economy that rewards low-emission innovation. 


\section{References}

Acworth, William, Christopher Kardish, and Kai Kellner. 2020. Carbon Leakage and Deep Decarbonization: Future-Proofing Carbon Leakage Protection. Berlin: International Carbon Action Partnership. https://icapcarbonaction.com/en/?option=com_attach\&task=download\&id=693.

Australian Department of Climate Change. 2008a. Carbon Pollution Reduction Scheme: Australia's Low Pollution Future. White Paper. Canberra: Commonwealth of Australia.

http://pandora.nla.gov.au/pan/99543/20090515-

1610/www.climatechange.gov.au/whitepaper/report/index.html.

Australian Department of Climate Change. 2008b. Carbon Pollution Reduction Scheme. Green Paper. Canberra: Commonwealth of Australia. http://pandora.nla.gov.au/pan/86984/200807181535/www.greenhouse.gov.au/greenpaper/report/pubs/greenpaper.pdf.

Australian Department of Climate Change and Energy Efficiency. 2011. Securing a Clean Energy Future: The Australian Government's Climate Change Plan. Canberra: Commonwealth of Australia . http://large.stanford.edu/courses/2012/ph240/aslani2/docs/CleanEnergyPlan-20120628-3.pdf.

Bennett, Paula. 2017. New Zealand Emissions Trading Scheme Review: Improving the ETS Framework. Cabinet Paper. Wellington: New Zealand Government. https://www.mfe.govt.nz/sites/default/files/media/Cabinet_\%20paper_NZETS_review_improving_the _ETS_framework.pdf.

Cabinet Environment, Energy and Climate Committee. 2019. New Zealand Emissions Trading Scheme: A Review of Industrial Allocation. Cabinet Minute ENV-19-MIN-0062. Wellington: New Zealand Cabinet. https://www.mfe.govt.nz/sites/default/files/media/Climate\%20Change/minute-of-decision-ENV-19MIN-0062.pdf.

California Air Resources Board. 2010. 'Appendix K - Leakage Analysis'. In Cap-and-Trade Regulation Initial Statement of Reasons. Sacramento, CA: California Air Resources Board. https://ww2.arb.ca.gov/sites/default/files/classic/regact/2010/capandtrade10/capv4appk.pdf.

California Air Resources Board. 2011. Appendix B: Development of Product Benchmarks for Allowance Allocation. Sacramento, CA: California Air Resources Board. https://ww3.arb.ca.gov/cc/capandtrade/meetings/072011/product-benchmarks.pdf.

California Air Resources Board. 2013. Appendix B: Leakage Risk Analysis for New and Modified Sectors. Sacramento, CA: California Air Resources Board. https://ww3.arb.ca.gov/regact/2013/capandtrade13/capandtrade13isorappb.pdf.

California Air Resources Board. 2018. 'Public Hearing to Consider the Proposed Amendments to the California Cap on Greenhouse Gas Emissions and Market-Based Compliance Mechanisms Regulation: Staff Report: Initial Statement of Reasons'. Sacramento, CA: California Air Resources Board. https://ww2.arb.ca.gov/sites/default/files/classic/regact/2018/capandtrade18/ct18isor.pdf.

California Air Resources Board. 2019. Final Regulation Order. Article 5: California Cap on Greenhouse Gas Emissions and Marked-Based Compliance Mechanisms. Sacramento, CA: California Air Resources Board. 
California Energy Commission. 2021. 2019 Total System Electric Generation. Sacramento: California Energy Commission. https://www.energy.ca.gov/data-reports/energy-almanac/california-electricitydata/2020-total-system-electric-generation/2019.

Coleman, Andrew, and Suzi Kerr. 2007. Economic Regrets. Report for the Climate Change Leadership Forum. Wellington: Motu Economic and Public Policy Research. https://www.motu.nz/ourresearch/environment-and-resources/emission-mitigation/emissions-trading/economic-regrets/.

Commonwealth of Australia. 2012. Establishing the Eligibility of Emissions-Intensive, Trade-Exposed Activities under the Jobs and Competitiveness Program and Renewable Energy Target. Canberra: Commonwealth of Australia.

Controller and Auditor-General. 2011. The Emissions Trading Scheme - Summary Information for Public Entities and Auditors. Wellington: Audit New Zealand. http://www.oag.govt.nz/2011/emissions-tradingscheme/docs/emissions-trading-scheme.pdf.

Ecofys, Fraunhofer Institute for Systems and Innovation Research, and Öko-Institut. 2009a. Methodology for the Free Allocation of Emission Allowances in the EU ETS Post 2012. Sector Report for the Aluminium Industry. European Commission.

Ecofys, Fraunhofer Institute for Systems and Innovation Research, and Öko-Institut. 2009b. Methodology for the Free Allocation of Emission Allowances in the EU ETS Post 2012. Sector Report for the Cement Industry. European Commission.

Ecofys, Fraunhofer Institute for Systems and Innovation Research, and Öko-Institut. 2009c. Methodology for the Free Allocation of Emission Allowances in the EU ETS Post 2012. Sector Report for the Iron and Steel Industry. European Commission.

Ecofys, Fraunhofer Institute for Systems and Innovation Research, and Öko-Institut. 2009d. Methodology for the Free Allocation of Emission Allowances in the EU ETS Post 2012. Sector Report for the Lime Industry. European Commission.

Environmental Protection Authority. 2018. New Zealand Emissions Trading Scheme Facts and Figures 2017. Wellington: Environmental Protection Authority.

Environmental Protection Authority. 2019a. 2018 Final Allocation Decisions. Wellington: Environmental Protection Authority. https://www.epa.govt.nz/industry-areas/emissions-trading-scheme/industrialallocations/decisions.

Environmental Protection Authority. 2019b. 2018 New Zealand Emissions Trading Scheme Report for the Period 1 July 2018 to 30 June 2019, Under Section 89 of the Climate Change Response Act 2002. Wellington: Environmental Protection Authority. https://www.epa.govt.nz/assets/Uploads/Documents/EmissionsTrading-Scheme/Reports/Annual-Reports/b450975461/2018-ETS-Annual-Report.pdf.

Environmental Protection Authority. 2019c. New Zealand Emissions Trading Scheme Facts and Figures 2018. Wellington: Environmental Protection Authority. https://www.epa.govt.nz/assets/Uploads/Documents/Emissions-Trading-Scheme/Reports/AnnualReports/2018-ETS-Facts-and-Figures.pdf. 
Environmental Protection Authority. 2021a. ETS Unit Movement Report. Wellington: Environmental Protection Authority. https://www.epa.govt.nz/industry-areas/emissions-trading-scheme/ets-reports/unitmovement.

Environmental Protection Authority. 2021b. Final Allocation Decisions. Wellington: Environmental Protection Authority. https://www.epa.govt.nz/industry-areas/emissions-trading-scheme/industrialallocations/decisions.

European Commission. 2012. Official Journal of the European Union. Communication from the Commission. Guidelines on Certain State Aid Measures in the Context of the Greenhouse Gas Emission Allowance Trading Scheme Post-2012. Brussels: European Commission.

European Commission. 2015. EU ETS Handbook. European Union. https://ec.europa.eu/clima/sites/clima/files/docs/ets_handbook_en.pdf.

European Commission. 2019a. EU Emissions Trading System (EU ETS). 2019. Brussels: European Commission https://ec.europa.eu/clima/policies/ets_en.

European Commission. 2019b. Guidance Document $N^{\circ} 9$ on the Harmonised Free Allocation Methodology for the EU-ETS Post 2020. Sector-Specific Guidance. Brussels: European Commission Directorate General Climate Action.

European Commission. 2020. Carbon Border Adjustment Mechanism. Inception Impact Assessment. Brussels: European Commission. https://ec.europa.eu/info/law/better-regulation/have-yoursay/initiatives/12228-Carbon-Border-Adjustment-Mechanism.

European Commission. 2021a. Carbon Border Adjustment Mechanism: Questions and Answers. Brussels: European Commission. https://ec.europa.eu/commission/presscorner/detail/en/qanda_21_3661.

European Commission. 2021b. Carbon Leakage. Brussels: European Commission. https://ec.europa.eu/clima/policies/ets/allowances/leakage_en.

European Commission. 2021c. Questions and Answers - Emissions Trading - Putting a Price on Carbon. Brussels: European Commission. https://ec.europa.eu/commission/presscorner/detail/en/qanda_21_3542.

European Commission. 2021d. Revision for Phase 4 (2021-2030). Brussels: European Commission. https://ec.europa.eu/clima/policies/ets/revision_en.

Fan, Bin, Yun Zhang, Xiuzhen Li, and Xiao Miao. 2019. Trade Openness and Carbon Leakage: Empirical Evidence from China's Industrial Sector. Energies, 12(6): 1101.

Fowlie, Meredith L., Mar Reguant, and Stephen P. Ryan. 2016. Measuring Leakage Risk. Sacramento, CA: California Air Resources Board. https://ww2.arb.ca.gov/sites/default/files/classic/cc/capandtrade/meetings/20160518/ucb-intlleakage.pdf.

High-Level Commission on Carbon Pricing and Competitiveness. 2019. Report of the High-Level Commission on Carbon Pricing and Competitiveness. Washington, DC: Carbon Pricing Leadership Coalition. https://openknowledge.worldbank.org/bitstream/handle/10986/32419/141917.pdf?isAllowed=y\&seq uence $=4$. 
International Carbon Action Partnership. 2019. USA - California Cap-and-Trade Program. International Carbon Action Partnership.

https://icapcarbonaction.com/en/?option=com_etsmap\&task=export\&format=pdf\&layout=list\&syste $\mathrm{ms}[]=45$.

International Carbon Action Partnership. 2020. Emissions Trading Worldwide: Status Report 2020. Berlin: International Carbon Action Partnership.

https://icapcarbonaction.com/en/?option=com_attach\&task=download\&id=677.

International Carbon Action Partnership. 2021. EU Emissions Trading System: General Information. Berlin: International Carbon Action Partnership. https://icapcarbonaction.com/en/ets-map?etsid=43.

Koch, Nicolas and Houdou Basse Mama. 2019. Does the EU Emissions Trading System Induce Investment Leakage? Evidence from German Multinational Firms. Energy Economics, 81: 479-492.

Leining, Catherine, Suzi Kerr and Bronwyn Bruce-Brand. 2019. The New Zealand Emissions Trading Scheme: Critical Review and Future Outlook for Three Design Innovations. Climate Policy, 20(2): 246-264. https://doi.org/10.1080/14693062.2019.1699773.

Li, Min and Zhang Binliang. 2020. Carbon Market Business Brief: China. IETA.

https://www.ieta.org/resources/Resources/CarbonMarketBusinessBrief/CarbonMarketBusinessBriefC hina_2020.pdf.

Ministry of Business, Innovation and Employment. 2020. Energy in New Zealand 20. Wellington: Ministry of Business, Innovation and Employment. https://www.mbie.govt.nz/dmsdocument/11679-energy-innew-zealand-2020.

Ministry for the Environment. 2009a. Departmental Report on the Climate Change Response (Moderated Emissions Trading) Amendment Bill: Stage 1. Wellington: Ministry for the Environment. https://www.parliament.nz/resource/ennz/49SCFE_ADV_00DBHOH_BILL9597_1_A16681/1cccb81e3d1b5b765d57fcbdcb18e0a9e5189fe7.

Ministry for the Environment. 2009b. Departmental Report on the Climate Change Response (Modified [Sic] Emissions Trading) Amendment Bill: Stage 2. Wellington: Ministry for the Environment. https://www.parliament.nz/resource/enNZ/49SCFE_ADV_00DBHOH_BILL9597_1_A18969/ac8baa1398f547e39c43557e8e64b62a7a92dc77.

Ministry for the Environment. 2009c. Development of Industrial Allocation Regulations under the New Zealand Emissions Trading Scheme: Consultation Document. Wellington: Ministry for the Environment.

Ministry for the Environment. 2013. Consultation on Proposed Updates to ETS Allocative Baselines. Wellington: Ministry for the Environment.

Ministry for the Environment. 2016. Industrial Allocation: NZUs for Industry. Wellington: Ministry for the Environment, 23 March.

Ministry for the Environment. 2018. Emissions Pricing Impact on Innovation and Competitiveness. Wellington: Ministry for the Environment.

Ministry for the Environment. 2019a. Impact Statement: A Phase-down of Industrial Allocation. Wellington: Ministry for the Environment. 
Ministry for the Environment. 2019b. Improvements to the New Zealand Emissions Trading Scheme: Summary of Consultation Responses. Wellington: Ministry for the Environment. https://environment.govt.nz/publications/improvements-to-the-new-zealand-emissions-tradingscheme-summary-of-consultation-responses/.

Ministry for the Environment. 2019c. Reforming the New Zealand Emissions Trading Scheme: Proposed Settings - Consultation Document. Wellington: Ministry for the Environment.

Ministry for the Environment. 2019d. The New Zealand Emissions Trading Scheme: Modelling the Electricity Allocation Factor: Issues Paper. Wellington: Ministry for the Environment. https://environment.govt.nz/publications/the-new-zealand-emissions-trading-scheme-modelling-theelectricity-allocation-factor-issues-paper/

Ministry for the Environment. 2020a. New Zealand Emissions Trading Scheme: Modelling the Electricity Allocation Factor. Website accessed 28 May 2020 (no longer available). Wellington: Ministry for the Environment.

Ministry for the Environment. 2020b. 'Update on NZ ETS Reform'. Slides, webinar held by Ministry for the Environment, Wellington, 2 June.

Ministry for the Environment. 2021a. Proposed Changes to NZ ETS and SGG Levy Regulations 2021: Consultation Document. Wellington: Ministry for the Environment.

Ministry for the Environment. 2021b. Reforming Industrial Allocation in the New Zealand Emissions Trading Scheme: Consultation Document. Wellington: Ministry for the Environment.

https://environment.govt.nz/assets/publications/IA-review-consultation-document.PDF.

Ministry for the Environment. 2021c. Release of Updates to NZ ETS Regulations and SGG Levy. Wellington: Ministry for the Environment. Media release 23 August 2021.

https://environment.govt.nz/news/release-of-updates-to-nz-ets-regulations-and-sgg-levy/.

Ministry of Business Innovation and Employment, and Energy Efficiency and Conservation Authority. 2017. Summary and Analysis of Submissions. Draft New Zealand Energy Efficiency and Conservation Strategy 2017-2022. Wellington: New Zealand Government.

Narassimhan, Easwaran, Kelly S. Gallagher, Stefan Koester, and Julio Rivera Alejo. 2018. Carbon Pricing in Practice: A Review of Existing Emissions Trading Systems. Climate Policy, 18(8): 967-991.

https://doi.org/10.1080/14693062.2018.1467827.

New Zealand Government. 2019. Climate Change Response (Emissions Trading Reform) Amendment Bill: Explanatory Note. Wellington: New Zealand Government.

New Zealand Government. 2020. Climate Change (Eligible Industrial Activities) Regulations 2010. Reprint as at 16 April 2020. Wellington: New Zealand Government.

http://www.legislation.govt.nz/regulation/public/2010/0189/latest/DLM3075101.html?src=qs.

Office of Parliamentary Counsel. 2013. Clean Energy Act 2011. 131.

Partnership for Market Readiness. 2015. Carbon Leakage: Theory, Evidence and Policy Design. Technical Note 11. Washington, DC: World Bank. 
Partnership for Market Readiness, and International Carbon Action Partnership. 2016. Emissions Trading in Practice: A Handbook on Design and Implementation. Washington, DC: World Bank. https://openknowledge.worldbank.org/bitstream/handle/10986/23874/ETP.pdf.

Refining NZ. 2021. Refining NZ Shareholders Vote to Approve Import Terminal Proposal. Notice to NZX, 6 August 2021. Ruakaka: Refining NZ. http://nzx-prod-s7fsd7f98s.s3-website-ap-southeast2.amazonaws.com/attachments/NZR/376853/351722.pdf.

Rio Tinto. 2021. NZAS Reaches Deal with Meridian to Extend Operations to 2024. Notice to ASX/LSA, 14 January 2021. London: Rio Tinto plc. https://www.nzas.co.nz/files/3455_2021011483129-1610566289.pdf. Secretaria de Medio Ambiente y Recursos Naturales, and Deutsche Gesellschaft für Internationale Zusammenarbeit. 2018. Distributing Allowances in the Mexican Emissions Trading System: Indicative Allocation Scenarios. German Federal Ministry for the Environment, Nature Conservation and Nuclear Safety.

Sense Partners. 2018. Countervailing Forces: Climate Targets and Implications for Competitiveness, Leakage and Innovation. Wellington: Sense Partners. https://environment.govt.nz/assets/Publications/Files/Countervailing-forces-Sense-Partners-2018FINAL-report.pdf

Verde, Stefano F., William Acworth, Christopher Kardish, and Simone Borghesi. 2020. Achieving Zero Emissions Under a Cap-And-Trade System. Florence: Florence School of Regulation.

https://cadmus.eui.eu/bitstream/handle/1814/67510/PB_2020_26_FSR.pdf?sequence=3. 